\title{
Production and nitrogen metabolism in lactating dairy cows fed finely ground field pea plus soybean meal or canola meal with or without rumen-protected methionine supplementation
}

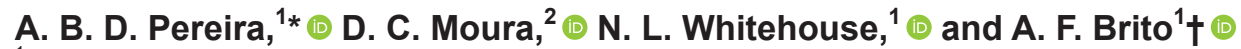 \\ ${ }^{1}$ Department of Agriculture, Nutrition, and Food Systems, University of New Hampshire, Durham 03824 \\ ${ }^{2}$ Instituto de Ciências Agrárias e Ambientais, Universidade Federal de Mato Grosso - Campus Sinop, MT, Brazil 78557-267
}

\begin{abstract}
We showed previously that dairy cows fed [diet dry matter (DM) basis] $25 \%$ finely ground field pea (GFP) plus rumen-protected (RP)-Met and RP-Lys had greater milk true protein yield and plasma Met concentration, but lower plasma His, compared with those fed GFP without rumen-protected AA supplementation. The goal of the present study was to investigate the effects of diets containing soybean meal (SBM) or canola meal (CM) with or without a source of RP-Met on production, nutrient digestibility, and $\mathrm{N}$ metabolism in cows fed 25\% GFP. Sixteen mid-lactation Holstein cows were used in a replicated $4 \times 4$ Latin square with a 2 $\times 2$ factorial arrangement of treatments (21-d periods). Cows were fed (DM basis) 35\% corn silage, $14 \%$ grasslegume haylage, $25 \% \mathrm{GFP}$, and $11 \% \mathrm{SBM}$ or $13.5 \%$ CM with or without $0.095 \%$ RP-Met supplementation as Smartamine M (Adisseo USA Inc., Alpharetta, GA). Protein source effects were observed for most production variables; cows fed diets containing CM plus GFP had greater DM intake, yields of milk and milk fat and true protein, and milk $\mathrm{N}$ efficiency than those offered SBM plus GFP. Feeding CM plus GFP also reduced the concentrations of milk urea $\mathrm{N}$ and plasma urea $\mathrm{N}$, and the urinary excretion of $\mathrm{NH}_{3} \mathrm{~N}$ and urea $\mathrm{N}$, suggesting improved $\mathrm{N}$ use efficiency. Moreover, replacing SBM with CM increased the concentrations of all essential AA (except Arg) in plasma collected from the coccygeal blood vessels. A protein source $\times$ RP-Met interaction was observed for the concentration of His in coccygeal plasma, with circulating His decreasing only when RPMet was supplemented to the diet containing SBM plus GFP. Based on the arteriovenous difference method,
\end{abstract}

Received June 28, 2019.

Accepted December 17, 2019.

*Present address: Purina Animal Nutrition LLC, Arden Hills, MN 55126.

†Corresponding author: andre.brito@unh.edu
Lys was the first limiting AA overall, with Met being the first limiting $\mathrm{AA}$ in diets that did not receive RPMet. Apparent total-tract digestibilities of DM, organic matter, $\mathrm{N}$, and acid detergent fiber increased with feeding SBM plus GFP versus CM plus GFP. Most variables were not affected by RP-Met supplementation, except plasma Met concentration, which increased by $63 \%$. Collectively, our results indicate that $\mathrm{CM}$ appears to be a better companion rumen-degradable protein source to GFP than SBM, due to improved yields of milk and milk protein and $\mathrm{N}$ use efficiency.

Key words: alternative feed, amino acid, milk yield, rumen-degradable protein

\section{INTRODUCTION}

Field pea (Pisum sativum) is a pulse crop commonly grown in the northern plains of the United States and Canada and typically used for human consumption (Gilbery et al., 2007). When food quality standards are not met, field pea is normally fed to livestock as one of the few feedstuffs that supply relatively high concentrations of CP $($ mean $=21 \%)$ and starch (mean $=44.9 \%$; Pereira et al., 2017). This unique nutritional composition makes field pea a potential substitute for protein or energy feeds such as soybean meal (SBM), corn, and barley (Gilbery et al., 2007; Pereira et al., 2017). However, most of the RDP in field pea consists of soluble protein, which may decrease DMI, milk yield, and $\mathrm{N}$ utilization in lactating dairy cows, particularly at high levels of dietary inclusion. For instance, Albrecht (2012) reported a quadratic decrease in DMI, and linear reductions in milk yield and concentration and yield of milk true protein in dairy cows fed incremental amounts of cracked field pea $(0,12,24$, or $36 \%$ of diet DM) at expense of ground corn and SBM. These negative responses in milk and milk true protein yields were more pronounced at higher levels of supplementation (i.e., 24 and $36 \%$ of diet DM), suggesting that depressed DMI or deficiency in the supply of digestible EAA, including Lys, Met, and His, could 
be involved. We demonstrated that supplementation of rumen-protected (RP) Met and Lys (RP-ML) to a diet containing (DM basis) $25 \%$ finely ground field pea (GFP) decreased the plasma concentrations of His, Leu, and Phe compared with GFP without RPML (Pereira et al., 2017). The plasma concentrations of His and Leu also dropped in dairy cows fed GFP plus RP-ML compared with a ground corn-SBM mix plus RP-ML (Pereira et al., 2017). However, RP-ML supplementation increased plasma Met by 63 and $15.2 \%$ with feeding GFP plus RP-ML or a ground cornSBM mix plus RP-ML, compared with the GFP-only diet, respectively. Altogether, our earlier results suggest that His, Leu, and Phe were limiting AA in GFP diets containing RP-ML and that Met was the first limiting AA when cows received $25 \%$ of the diet DM as GFP. Thus, further research is needed to better understand the effect of rumen-protected AA and different RDP sources on production and $\mathrm{N}$ metabolism of dairy cows fed high levels of GFP.

Martineau et al. (2013, 2014) demonstrated through 2 meta-analyses that canola meal $(\mathbf{C M})$ increased DMI, milk yield, milk $\mathrm{N}$ efficiency (milk $\mathrm{N} / \mathrm{N}$ intake), and plasma concentrations of EAA when replacing several protein sources, including SBM, in isonitrogenous diets. Specifically, CM tended to elevate plasma concentrations of His, Leu, and Phe and increased Met (Martineau et al., 2014), indicating that CM may be able to reduce the apparent shortage of these EAA in dairy cows fed GFP (Pereira et al., 2017). We are not aware of any study to date that has investigated the effects of GFP supplemented with RP-Met on production and $\mathrm{N}$ metabolism in dairy cows receiving SBM or CM. Patton et al. (2015) reported that increased postruminal supply of Lys or Met alone caused changes in the plasma concentrations of many EAA. However, Met appeared to be more potent than Lys, causing a decrease in the concentrations of all EAA except Arg and Lys (Patton et al., 2015). Therefore, feeding GFP plus RP-Met in diets with or without CM may help us understand the reduction in the plasma concentrations of His, Leu, and Phe observed previously (Pereira et al., 2017).

Our central hypothesis is that, compared with SBM plus GFP, feeding CM plus GFP would increase yields of milk and milk true protein due to improved DMI. We also hypothesized that in cows fed GFP plus RPMet, CM would lead to greater plasma concentrations of EAA than SBM. The objective of this study was to evaluate the effect of SBM versus CM with or without RP-Met on production, apparent total-tract digestibility of nutrients, and $\mathrm{N}$ metabolism in Holstein cows fed the same amounts of GFP.

\section{MATERIALS AND METHODS}

The experiment was conducted at the University of New Hampshire Fairchild Dairy Teaching and Research Center, located in Durham, NH $\left(43^{\circ} 14^{\prime} \mathrm{N}, 70^{\circ} 95^{\prime} \mathrm{W}\right)$ from February 17 to May 11, 2016. Care and handling of animals were approved in accordance to the University of New Hampshire Institutional Animal Care and Use Committee guidelines (IACUC protocol no. 151206).

\section{Animals, Experimental Design, and Diets}

Twelve multiparous Holstein cows averaging (mean $\pm \mathrm{SD}) 153 \pm 31 \mathrm{DIM}$ and $738 \pm 62 \mathrm{~kg}$ of BW, and 4 primiparous cows averaging $122 \pm 16$ DIM and 612 $\pm 42 \mathrm{~kg}$ of $\mathrm{BW}$ at the beginning of the study were used. Cows were randomly assigned to 1 of 4 treatment sequences in a replicated $4 \times 4$ Latin square design. Animals were distributed to squares to balance for differences in DIM, milk yield, and parity. Each experimental period lasted $21 \mathrm{~d}$, with $14 \mathrm{~d}$ for diet adaptation and $7 \mathrm{~d}$ for data and sample collection. Squares were also balanced against potential first-order carryover effects in subsequent periods, as each treatment immediately preceded and followed every other exactly once in each square (Williams, 1949). Diets were prepared as TMR and fed twice daily at $0515 \mathrm{~h}$ and 1615 h using a Super Data Ranger mixer (American Calan Inc., Northwood, NH). Approximately 35 and $65 \%$ of the daily TMR was allocated during the morning and afternoon feedings, respectively, and the amount of feed offered was adjusted daily to keep about $5 \%$ orts. This TMR allocation protocol was adopted to account for uneven intervals between feeding times $(\sim 11 \mathrm{~h}$ from 0515 to $1615 \mathrm{~h}$ and $13 \mathrm{~h}$ from 1615 to $0515 \mathrm{~h}$ ).

Cows were housed in a tiestall barn. Measurements of the amount of feed offered and refused were taken using a Super Data ranger (American Calan Inc.). Intake was individualized using wooden feed tubs $(90 \times 90 \times 90$ $\mathrm{cm})$ placed in front of each cow in the feed bunk. The experimental diets were formulated to yield (DM basis) a 49:51 forage-to-concentrate ratio, with the forage portion of the rations consisting of $35 \%$ corn silage and $14 \%$ grass-legume haylage mix. The following treatments (DM basis) were fed: (1) $11 \% \mathrm{SBM}$ and $25 \%$ GFP (SB diet); (2) 11\% SBM, 25\% GFP, and $0.095 \%$ RPMet (SB+RP-Met diet); (3) 13.5\% CM and 25\% GFP (CAN diet); and (4) 13.5\% CM, 25\% GFP, and $0.095 \%$ RPMet (CAN+RP-Met diet). Smartamine M (Adisseo USA Inc., Alpharetta, GA), which contains $75 \%$ DL-Met coated with 2-vinylpyridine-co-styrene and relative bioavailability of $80 \%$ (Chirgwin et al., 2015), 
determined using the plasma free AA dose-response technique (Whitehouse et al., 2017), was used as the RP-Met supplement. Twenty-seven grams per day of Smartamine M was placed on top of the TMR offered to individual cows and mixed by hand to prevent sorting and ensure a homogeneous blend of RP-Met in the ration. Diets were formulated using the NRC (2001) model to meet the nutrient requirements (except MP) of a Holstein cow producing $42 \mathrm{~kg} / \mathrm{d}$ of milk with $3.6 \%$ milk fat and $3.2 \%$ milk true protein, consuming $25 \mathrm{~kg} / \mathrm{d}$ of DMI and weighing $650 \mathrm{~kg}$ of BW. Body weight was measured during 2 consecutive days before the beginning of the study and in the last $2 \mathrm{~d}$ of each experimental period (data not shown).

\section{Feed Sampling and Analyses}

Two samples each of corn silage and grass-legume haylage were obtained daily throughout the experiment, immediately before mixing into the TMR. The first subsample of each forage source was composited every $3 \mathrm{~d}$ and dried using a microwave (Model R209KK 700 Watts; Sharp Electronics, Osaka, Japan) for adjustments of diet DM. The second subsample was refrigerated at $4^{\circ} \mathrm{C}$, pooled weekly, lyophilized $(48 \mathrm{~h}$ using a Labconco freeze-drier 5; Kansas City, MO), and stored in resealable bags. Samples of TMR and orts were collected from d 14 to 21 of each experimental period, refrigerated immediately after collection, and pooled by treatment. Concentrate samples were collected by period and composited over the experiment, as they came from the same lot. Orts were dried in a forced-air oven (1380FMS; VWR Scientific, Radnor, $\mathrm{PA})$ at $55^{\circ} \mathrm{C}$ for $48 \mathrm{~h}$. All dried samples were ground to pass through a 1-mm screen (Wiley mill; Arthur H. Thomas Co., Philadelphia, PA), packed in labeled resealable bags, and shipped to a commercial laboratory for wet chemistry analyses (Dairy One Cooperative Inc., Ithaca, NY).

Forage and concentrate samples were analyzed for DM, CP, soluble CP, $\alpha$-amylase treated ash-free NDF (aNDFom), ADF, NDIN, ADIN, ADL, starch, ethanol-soluble carbohydrates, ether extract, ash, and individual minerals, following the procedures used by Dairy One Cooperative Inc. (https://dairyone.com/ download/forage-forage-lab-analytical-procedures / ?wpdmdl=13889\&refresh $=5$ dc162501747e1572954704; accessed Nov. 5, 2019). Samples of dietary ingredients were further ground (Wiley mill, Arthur H. Thomas Co.) to pass through a 0.5 - $\mathrm{mm}$ screen and used for determination of AA by cation exchange chromatography (cIEC)-HPLC coupled with post-column ninhydrin derivatization, with norleucine as the internal standard (method 982.30; AOAC International, 2016; University of Missouri Agricultural Experiment Station Chemical Laboratory, Columbia). Tryptophan was determined after alkaline hydrolysis, and sulfur AA were analyzed after performic acid oxidation (method 988.15; AOAC International, 2016). Orts were analyzed for DM, CP, aNDFom, ADF, and ash, as done for feed samples.

\section{Milk Sampling and Analyses}

Cows were milked twice a day at $0500 \mathrm{~h}$ and 1600 $\mathrm{h}$, with milk yield recorded throughout the experiment. Milk samples were collected during 6 consecutive milkings from d 19 to 21 of each experimental period, using vials containing 2-bromo-2-nitropropane-1,3 diol, pooled by cow according to morning and afternoon milk weights, and kept refrigerated at $4^{\circ} \mathrm{C}$ until shipped for analysis at Dairy One Cooperative Inc. Samples were analyzed for fat, true protein, lactose, SNF, TS, and MUN by mid-infrared reflectance spectroscopy in a Milkoscan (Foss Inc., Hillerød, Denmark), and SCC was determined by flow cytometry in a Fossomatic (Foss Inc.). Yields of 4\% FCM and ECM were calculated using the equations reported by Gaines and Davidson (1923) and Tyrrell and Reid (1965), respectively.

\section{Blood Sampling and Analyses}

Blood samples were taken approximately $4 \mathrm{~h}$ after the morning feeding on d 19 and 20 of each experimental period from coccygeal vessels (CGV; artery or vein) and the subcutaneous abdominal vein, commonly known as the mammary vein (MV), of each cow into evacuated tubes containing 15\% EDTA (Monoject Covidien, Mansfield, MA). After collection, tubes were immediately transported to the laboratory and centrifuged $\left(2,155 \times g\right.$ for 20 min at $\left.4^{\circ} \mathrm{C}\right)$ using an Eppendorf Centrifuge model 5810 (Eppendorf, Hamburg, Germany). Four milliliters of CGV or MV plasma were added to $16 \times 100 \mathrm{~mm}$ glass culture tubes containing $1 \mathrm{~mL}$ of $15 \%$ (wt/vol) 5-sulfosalicylic acid solution, mixed using a vortex (Mini Vortexer; VWR International, Bridgeport, NJ), and kept for 10 min at $4^{\circ} \mathrm{C}$. Tubes were recentrifuged $\left(2,155 \times g\right.$ for $20 \mathrm{~min}$ at $\left.4^{\circ} \mathrm{C}\right)$ and $0.6-\mu \mathrm{L}$ aliquots of supernatants were pooled over the 2 sampling days by cow per period and stored in cryovials at $-80^{\circ} \mathrm{C}$ until shipped to the University of Missouri Experimental Station Chemical Laboratories for plasma AA and urea N (PUN) analyses following the methods of Deyl et al. (1986) and Fekkes (1996) using cIEC-HPLC, as previously stated. Extraction ef- 
ficiency of AA by the mammary gland was calculated using the arteriovenous (A-V) difference method, as follows:

$$
\begin{gathered}
\text { Extraction efficiency }(\%)= \\
{[\mathrm{CGV} \text { plasma AA }(\mu M)-\mathrm{MV} \text { plasma AA }(\mu M)] /} \\
\text { CGV plasma AA }(\mu M) \times 100 .
\end{gathered}
$$

\section{Urinary and Fecal Sampling and Analyses}

Spot urinary samples were obtained for 2 consecutive days (d 19 and 20 of each period) at $0700 \mathrm{~h}, 1500 \mathrm{~h}$, and $2300 \mathrm{~h}$ during voluntary urination or through stimulation of the pudendal nerve, massaging the area below the vulva, with samples immediately transported to the laboratory and vortexed. Next, $1.6 \mathrm{~mL}$ of urine from each time point was pipetted into $50-\mathrm{mL}$ centrifuge tubes containing $38.4 \mathrm{~mL}$ of $0.072 \mathrm{~N} \mathrm{H}_{2} \mathrm{SO}_{4}$ to obtain composited urine samples by cow per period over the 2 $\mathrm{d}$ to yield a total of $9.6 \mathrm{~mL}$ of urine. Urine samples were stored at $-20^{\circ} \mathrm{C}$ before analysis of nitrogenous metabolites. After thawing at room temperature, urine samples were analyzed colorimetrically for concentrations of creatinine (assay kit no. 500701; Cayman Chemical Co., Ann Arbor, MI) using a microplate reader set at a wavelength of $492 \mathrm{~nm}$, allantoin (Chen et al., 1992), total N (micro-Kjeldahl analysis, AOAC, 1990; Dairy One Forage Laboratory Inc.), and urea N (diacetylmonoxime method of Rosenthal, 1955). Urinary urea N and allantoin were read at wavelengths of 540 and 522 $\mathrm{nm}$, respectively, on a UV/visible spectrophotometer (Beckman Coulter Inc., Pasadena, CA). Subsamples of $7 \mathrm{~mL}$ of urine per sampling point were added to $50-\mathrm{mL}$ centrifuge tubes containing $1.2 \mathrm{~mL}$ of $6 \mathrm{~N} \mathrm{HCl}$, pooled over the 2 sampling days, and frozen at $-20^{\circ} \mathrm{C}$ for later analysis of $\mathrm{NH}_{3}$. Samples for $\mathrm{NH}_{3}$ analysis were thawed at room temperature, vortexed, and centrifuged at $3,125 \times g$ for $20 \mathrm{~min}$ at $22^{\circ} \mathrm{C}$. Ten milliliters of supernatant was then added to a beaker containing $1 \mathrm{~mL}$ of pH ionic strength adjuster (Orion 951211; Thermo Fisher Scientific, Waltham, MA) with released gaseous $\mathrm{NH}_{3}$ measured using an ion-selective electrode meter (Orion Star A214 Benchtop pH/ISE Meter; Thermo Fisher), and finally converted to $\mathrm{NH}_{3} \mathrm{~N}$. Daily urinary volume was estimated from the urinary concentration of creatinine, assuming a constant creatinine excretion rate of $29 \mathrm{mg} / \mathrm{kg}$ of BW (Valadares et al., 1999).

Fecal grab samples were collected during voluntary defecation or directly from the rectum concurrently with the urinary sampling. Samples were pooled by cow based on fresh weight $(\sim 250 \mathrm{~g} /$ sampling $)$ over $\mathrm{d}$ 19 and 20, to obtain a single composite, and stored at $-20^{\circ} \mathrm{C}$ in resealable bags. At the end of each sampling period, pooled fecal samples were thawed, placed in aluminum trays, and kept inside a forced-air oven at $55^{\circ} \mathrm{C}$ until completely dried $(\sim 72 \mathrm{~h})$. Dried samples were ground to pass through a 1-mm screen and analyzed for DM, CP, aNDFom, ADF, and starch as done for feed samples. Approximately $0.5 \mathrm{~g}$ of TMR, feeds, and feces were weighed into Ankom F57 bags (Ankom Technology, Macedon, NY), placed in 1 larger laundry bag, and inserted in the rumen of 1 ruminally cannulated, late-lactation multiparous Holstein cow fed a corn silage and grass haylage-based TMR (52:48 forage-to-concentrate ratio) for $12 \mathrm{~d}$. After removal from the rumen, bags were rinsed with tap water and analyzed in-house for ADF using an Ankom ${ }^{2000}$ fiber analyzer (Ankom Technology). Indigestible ADF was used as the internal marker to estimate fecal output of DM and apparent total-tract digestibility of nutrients (Cochran et al., 1986; Huhtanen et al., 1994).

\section{Statistical Analyses}

Data were analyzed using the MIXED procedure of SAS (SAS version 9.4; SAS Institute Inc., Cary, NC) according to a replicated $4 \times 4$ Latin square design with a $2 \times 2$ factorial arrangement of treatments. The following model was used:

$$
\begin{aligned}
\mathrm{Y}_{\mathrm{ijklm}}=\mu & +\mathrm{Sq}_{\mathrm{i}}+\mathrm{P}_{\mathrm{j}}+\mathrm{C}_{\mathrm{k}(\mathrm{i})}+\mathrm{PS}_{1}+\text { RP-Met }_{\mathrm{m}} \\
& +\mathrm{PS} \times \mathrm{RP} \text { Met }_{\mathrm{lm}}+\varepsilon_{\mathrm{ijklm}},
\end{aligned}
$$

where $Y_{\mathrm{ijk} k m}=$ dependent variable, $\mu=$ overall mean, $\mathrm{Sq}_{\mathrm{i}}=$ fixed effect of the ith square, $\mathrm{P}_{\mathrm{j}}=$ fixed effect of the jth period, $\mathrm{C}_{\mathrm{k}(\mathrm{i})}=$ random effect of the kth cow within the ith square, $\mathrm{PS}_{1}=$ fixed effect of the lth protein source (SB vs. CAN diet), RP-Met $\mathrm{m}_{\mathrm{m}}=$ fixed effect of the mth RP-Met supplementation (yes or no), PS $\times$ RP-Met ${ }_{l m}=$ interaction between the lth protein source and mth RP-Met supplementation, and $\varepsilon_{\mathrm{ijklm}}=$ residual error term. The main effects of protein source and RPMet supplementation and the protein source $\times$ RP-Met interaction were tested using ANOVA. Significance was declared at $P \leq 0.05$ and trends at $0.05<P \leq 0.10$.

\section{RESULTS AND DISCUSSION}

\section{Dietary Nutrient Composition}

The nutritional composition of feedstuffs used in the experimental diets is presented in Table 1 , and the ingredient and nutritional compositions of the 2 basal diets fed are shown in Table 2. The GFP tested 19.8\% CP, $75 \%$ soluble CP (\% of CP), and $49.5 \%$ starch 
(Table 1$)$, thus, slightly lower in $\mathrm{CP}(-1.2$ percentage units) but greater in soluble CP (+6 percentage units) and starch $(+4.6$ percentage units $)$ than the GFP fed by Pereira et al. (2017). The dietary concentration of $\mathrm{CP}$ was similar and averaged $16.9 \%$ across treatments (Table 2). Both aNDFom and ADF concentrations were greater in the CAN than the SB diet (Table 2) because of increased contents of aNDFom $(+21$ percentage units) and $\mathrm{ADF}$ (+14 percentage units) in $\mathrm{CM}$ compared with SBM (Table 1). Starch concentration was 2.2 percentage units greater in the SB than the CAN diet, likely in response to elevated dietary proportions of ground corn, steam-flaked corn, and corn dry distillers grains with solubles in the SB treatment (Table 2).

Table 1. Nutrient composition of feedstuffs used in the experimental diets (\% of DM, unless otherwise noted)

\begin{tabular}{|c|c|c|c|c|c|c|c|c|c|}
\hline Item & $\begin{array}{l}\text { Corn } \\
\text { silage }\end{array}$ & $\begin{array}{c}\text { Grass-legume } \\
\text { haylage }\end{array}$ & $\begin{array}{c}\text { Canola } \\
\text { meal }\end{array}$ & $\begin{array}{c}\text { Soybean } \\
\text { meal }\end{array}$ & $\begin{array}{l}\text { Finely ground } \\
\text { field pea }\end{array}$ & $\begin{array}{l}\text { Ground } \\
\text { corn }\end{array}$ & $\begin{array}{l}\text { Steam-flaked } \\
\text { corn }\end{array}$ & DDGS $^{1}$ & $\begin{array}{c}\text { Citrus } \\
\text { pulp }\end{array}$ \\
\hline DM, $\%$ of fresh matter & 44.0 & 36.1 & 93.8 & 94.6 & 92.1 & 94.0 & 96.6 & 92.6 & 89.6 \\
\hline $\mathrm{CP}$ & 7.55 & 17.6 & 41.8 & 52.1 & 19.8 & 8.30 & 7.50 & 29.3 & 7.50 \\
\hline aNDFom $^{2}$ & 37.8 & 55.7 & 28.8 & 7.90 & 10.8 & 9.00 & 6.90 & 36.5 & 20.3 \\
\hline $\mathrm{ADF}$ & 22.6 & 38.9 & 21.2 & 7.20 & 8.00 & 3.00 & 3.00 & 12.5 & 17.3 \\
\hline $\mathrm{NDICP}^{3}$ & 1.00 & 3.15 & 6.60 & 5.90 & 3.20 & 0.90 & 1.10 & 6.90 & 4.10 \\
\hline Starch & 39.1 & 1.05 & 1.20 & 1.20 & 49.5 & 73.9 & 72.8 & 2.00 & 10.6 \\
\hline $\mathrm{ESC}^{5}$ & 1.45 & 1.35 & 8.70 & 13.2 & 4.00 & 1.20 & 1.10 & 5.00 & 19.2 \\
\hline Ether extract & 3.30 & 5.30 & 4.70 & 1.50 & 2.10 & 3.70 & 3.30 & 17.5 & 2.80 \\
\hline Ash & 3.41 & 9.14 & 7.30 & 6.71 & 3.39 & 1.30 & 1.20 & 6.60 & 7.10 \\
\hline $\mathrm{Ca}$ & 0.21 & 0.70 & 0.72 & 0.32 & 0.23 & 0.02 & 0.02 & 0.03 & 2.06 \\
\hline $\mathrm{P}$ & 0.26 & 0.41 & 1.09 & 0.83 & 0.38 & 0.33 & 0.25 & 0.94 & 0.15 \\
\hline $\mathrm{Mg}$ & 0.15 & 0.29 & 0.58 & 0.32 & 0.15 & 0.11 & 0.08 & 0.34 & 0.15 \\
\hline $\mathrm{Mn}, \mathrm{mg} / \mathrm{kg}$ & 10.0 & 52 & 66.0 & 37.0 & 18.0 & 5.00 & 4.00 & 13.0 & 15.0 \\
\hline $\mathrm{Mo}, \mathrm{mg} / \mathrm{kg}$ & 1.20 & 3.55 & 1.50 & 6.00 & 2.20 & 0.90 & 0.90 & 1.14 & 0.90 \\
\hline S & 0.15 & 0.29 & 0.77 & 0.47 & 0.18 & 0.10 & 0.09 & 0.46 & 0.13 \\
\hline $\mathrm{Cl}$ ion & 0.21 & 0.70 & 0.06 & 0.04 & 0.13 & 0.05 & 0.05 & 0.17 & 0.10 \\
\hline \multicolumn{10}{|l|}{ EAA, $\%$ of $\mathrm{CP}$} \\
\hline Arg & 1.67 & 2.50 & 6.32 & 6.62 & 8.12 & 4.02 & 3.85 & 4.45 & 2.75 \\
\hline His & 1.52 & 2.05 & 3.17 & 2.76 & 2.74 & 3.01 & 3.39 & 3.11 & 1.59 \\
\hline Ile & 3.64 & 4.36 & 4.35 & 4.50 & 4.83 & 3.14 & 3.70 & 4.12 & 3.04 \\
\hline Leu & 9.24 & 7.50 & 7.58 & 7.41 & 8.55 & 10.1 & 12.9 & 12.2 & 5.79 \\
\hline Lys & 3.03 & 5.26 & 6.37 & 6.10 & 8.06 & 3.64 & 3.54 & 3.47 & 2.61 \\
\hline Met & 1.82 & 1.60 & 2.11 & 1.32 & 1.21 & 1.63 & 2.00 & 1.95 & 1.16 \\
\hline Phe & 3.79 & 4.68 & 4.21 & 4.74 & 5.43 & 4.14 & 5.08 & 4.85 & 3.47 \\
\hline Thr & 3.18 & 4.04 & 4.48 & 3.66 & 4.22 & 3.14 & 3.54 & 3.94 & 2.90 \\
\hline Trp & 0.45 & 0.58 & 1.25 & 1.36 & 0.99 & 0.75 & 0.92 & 0.72 & 0.87 \\
\hline \multicolumn{10}{|l|}{ NEAA, $\%$ of $\mathrm{CP}$} \\
\hline Ser & 3.03 & 3.08 & 3.81 & 4.04 & 4.66 & 3.77 & 4.62 & 4.52 & 2.90 \\
\hline Tyr & 0.30 & 0.32 & 0.16 & 0.11 & 2.91 & 0.13 & 0.15 & 0.04 & 1.74 \\
\hline Tau & 1.67 & 2.12 & 2.69 & 3.18 & 0.05 & 1.76 & 1.85 & 3.76 & 0.29 \\
\hline
\end{tabular}

${ }^{1}$ DDGS $=$ corn dried distillers grains plus solubles.

${ }^{2}$ aNDFom $=$ amylase-treated, exclusive of ash NDF.

${ }^{3} \mathrm{NDICP}=$ neutral detergent insoluble $\mathrm{CP}$.

${ }^{4} \mathrm{ADICP}=$ acid detergent insoluble $\mathrm{CP}$.

${ }^{5} \mathrm{ESC}=$ ethanol-soluble carbohydrates. 
Table 2. Ingredient and nutritional composition of the experimental diets

\begin{tabular}{|c|c|c|}
\hline \multirow[b]{2}{*}{ Item } & \multicolumn{2}{|c|}{$\operatorname{Diet}^{1}$} \\
\hline & $\mathrm{SB}$ & $\mathrm{CAN}$ \\
\hline \multicolumn{3}{|l|}{ Ingredient, $\%$ of diet DM } \\
\hline Corn silage & 35.0 & 35.0 \\
\hline Grass-legume haylage & 14.0 & 14.0 \\
\hline Ground corn & 6.50 & 5.00 \\
\hline Steam-flaked corn & 3.20 & 2.50 \\
\hline Corn dried distillers grains plus solubles & 1.30 & 1.00 \\
\hline Finely ground field pea & 25.0 & 25.0 \\
\hline Soybean meal & 11.0 & - \\
\hline Canola meal & - & 13.5 \\
\hline Citrus pulp & 1.50 & 1.50 \\
\hline Minerals and vitamins ${ }^{2}$ & 2.50 & 2.50 \\
\hline \multicolumn{3}{|c|}{ Nutritional composition, \% of DM (unless otherwise noted) } \\
\hline $\mathrm{DM}, \%$ of fresh matter & 42.5 & 41.9 \\
\hline $\mathrm{CP}$ & 17.0 & 16.8 \\
\hline aNDFom $^{3}$ & 21.0 & 23.3 \\
\hline $\mathrm{ADF}$ & 17.6 & 19.5 \\
\hline $\mathrm{NDICP}^{4}$ & 2.59 & 2.75 \\
\hline $\mathrm{ADICP}^{5}$ & 0.98 & 0.87 \\
\hline Starch & 35.9 & 33.7 \\
\hline ADL & 2.01 & 3.16 \\
\hline Ether extract & 3.39 & 3.73 \\
\hline Ash & 7.37 & 7.50 \\
\hline $\mathrm{Ca}$ & 0.68 & 0.73 \\
\hline $\mathrm{P}$ & 0.43 & 0.48 \\
\hline $\mathrm{NE}_{\mathrm{L}}, \mathrm{Mcal} / \mathrm{kg}$ & 1.57 & 1.55 \\
\hline \multicolumn{3}{|c|}{$\begin{array}{l}{ }^{1} \mathrm{SB}=\text { soybean meal plus finely ground field pea basal diet; } \mathrm{CAN}= \\
\text { canola meal plus finely ground field pea basal diet. }\end{array}$} \\
\hline \multicolumn{3}{|c|}{$\begin{array}{l}{ }^{2} \text { Mineral and vitamin mix provided on as-fed basis: } 297 \mathrm{mg} / \mathrm{kg} \text { monen- } \\
\text { sin sodium (Rumensin; Elanco, Greenfield, IN), } 13.6 \% \mathrm{Ca}, 1.31 \% \mathrm{P} \\
4.77 \% \mathrm{Mg}, 0.18 \% \mathrm{~K}, 0.72 \% \mathrm{~S}, 32 \mathrm{mg} / \mathrm{kg} \mathrm{Co}, 422 \mathrm{mg} / \mathrm{kg} \mathrm{Cu}, 1,290 \mathrm{mg} / \\
\mathrm{kg} \mathrm{Mn}, 8.97 \mathrm{mg} / \mathrm{kg} \text { Se, } 2,260 \mathrm{mg} / \mathrm{kg} \mathrm{Zn} \text {, and } 87.1 \mathrm{KIU} / \mathrm{kg} \text { vitamin A. } \\
{ }^{3} \text { aNDFom = amylase-treated, exclusive of ash NDF. } \\
{ }^{4} \mathrm{NDICP}=\text { neutral detergent insoluble } \mathrm{CP} . \\
{ }^{5} \mathrm{ADICP}=\text { acid detergent insoluble } \mathrm{CP} .\end{array}$} \\
\hline
\end{tabular}

\section{Effects of Protein Source and Protein Source × Rumen-Protected Methionine Interaction}

Overall, only a few significant protein source $\times$ RPMet supplementation interactions were observed in the present study. However, the study set as a $2 \times$ 2 factorial arrangement of treatments was specifically designed with the intent to detect significant interactions for several variables. Therefore, our hypothesis for obtaining protein source $\times$ RP-Met interactions was largely not supported.

Production Responses and PUN. Treatment effects on DMI, milk yield, feed efficiency, concentrations and yields of milk components, PUN, and milk SCC are presented in Table 3. A protein source effect was observed for DMI, with cows fed CAN and CAN+RP-Met showing a $3.2 \%$ increase $(P<0.01)$ in DMI compared with those offered SB and SB+RP-Met. Elevated DMI when replacing SBM with $\mathrm{CM}$ has been reported in the literature. Brito and Broderick (2007) observed a 2.9\% increase in DMI when feeding CM (mean $=24.9 \mathrm{~kg} / \mathrm{d}$ ) versus SBM (mean $=24.2 \mathrm{~kg} / \mathrm{d}$ ) to lactating dairy cows. In the subsequent study of Broderick et al. (2015), DMI improved by $1.6 \%$ in lactating dairy cows receiving $\mathrm{CM}$ instead of SBM (25.2 vs. $24.8 \mathrm{~kg} / \mathrm{d}$, respectively). However, Paula et al. (2018) reported no change in DMI when comparing SBM (mean $=25.4 \mathrm{~kg} / \mathrm{d}$ ) with $\mathrm{CM}$ diets $($ mean $=26.4 \mathrm{~kg} / \mathrm{d})$, despite the $1 \mathrm{~kg} /$ d difference in DMI between treatments being larger than those obtained by Brito and Broderick (2007) or Broderick et al. (2015). Both Huhtanen et al. (2011) and Martineau et al. (2013) showed in their meta-analyses that substituting SBM with CM generally enhanced DMI. Huhtanen et al. (2011) hypothesized that elevated DMI in response to CM may result from increased energy demand due to improved lactational performance ("pull effect"), possibly induced by a greater EAA supply or a more balanced profile of EAA when CM replaced SBM in dairy diets. In the current experiment, the concentrations of total EAA in CGV and MV plasma (Tables 4 and 5 , respectively) were significantly greater in cows offered CAN and CAN+RP-Met than in those offered $\mathrm{SB}$ or SB+RP-Met diets, consistent with the "pull effect" hypothesis of Huhtanen et al. (2011).

Cows fed the CAN and CAN + RP-Met diets had greater yields of milk $(+4.2 \% ; P<0.001), 4 \% \mathrm{FCM}$ $(+4.0 \% ; P<0.01)$, and $\mathrm{ECM}(+3.8 \% ; P<0.01)$ than did those offered the SB and SB+RP-Met diets (Table $3)$. These responses are directly associated with the $3.2 \%$ increase in DMI observed for cows receiving diets containing CM versus SBM. Broderick et al. (2015) also reported increased yields of milk and ECM concurrently with improved DMI in dairy cows fed CM rather than SBM, which agrees with Huhtanen et al. (2011) and Gidlund et al. (2015). In contrast, Maxin et al. (2013a) and Paula et al. (2018) did not find any differences in DMI or yields of milk, 3.5\% FCM, or ECM when comparing SBM with CM. Although Brito and Broderick (2007) reported no changes in the amounts of milk and $3.5 \%$ FCM produced by dairy cows receiving SBM or CM, DMI did increase with feeding CM. Martineau et al. (2013) demonstrated in their meta-analysis that milk yield responded positively to the substitution of several protein sources with CM. However, no differences in 4\% FCM or ECM production were found when replacing SBM with CM (Martineau et al., 2013). Recently, Martineau et al. (2019) concluded, based on a follow-up meta-analysis, that there was no benefit to production responses from blending $\mathrm{CM}$ with another protein source, unless CM is used to alleviate shortages in the EAA profile of the companion feed. In fact, in the present experiment, blending CM with GFP led to greater milk yield than did combining SBM with GFP. It is conceivable that the digestible EAA profile of CM, 
Table 3. Least squares means for DMI, milk yield, feed efficiency, concentrations and yields of milk components, and concentration of plasma urea N (PUN) in lactating dairy cows fed diets containing finely ground field pea plus soybean meal or canola meal, with or without rumenprotected Met (RP-Met) ${ }^{1}$

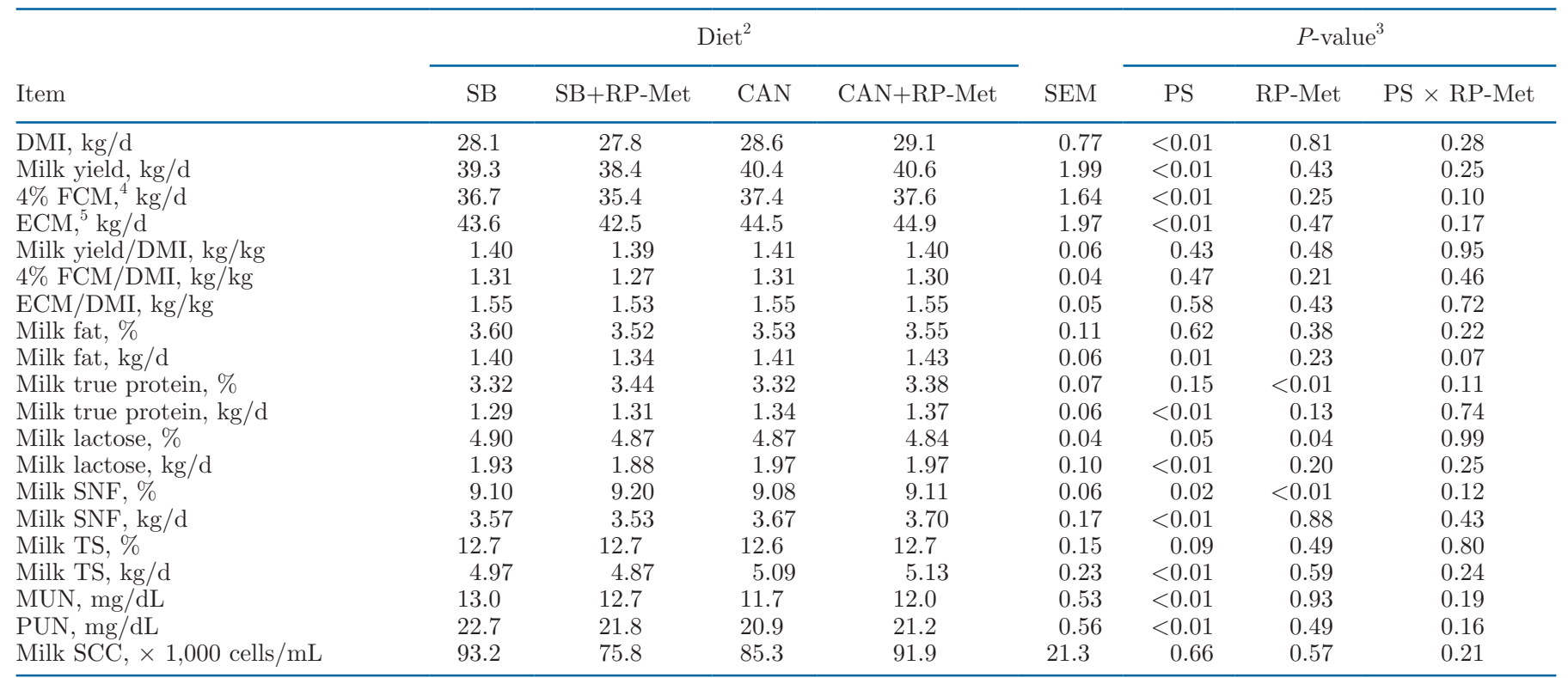

${ }^{1}$ RP-Met is Smartamine M (Adisseo USA Inc., Alpharetta, GA) supplemented at 0.095\% (27 g/d) of diet DM.

${ }^{2} \mathrm{SB}=$ soybean meal plus finely ground field pea; $\mathrm{SB}+\mathrm{RP}-\mathrm{Met}=$ soybean meal plus finely ground field pea supplemented with RP-Met; CAN = canola meal plus finely ground field pea; and CAN+RP-Met = canola meal plus finely ground field pea supplemented with RP-Met.

${ }^{3}$ Probability of protein source (PS) main effect (SB and SB+RP-Met vs. CAN and CAN+RP-Met); probability of RP-Met supplementation main effect (SB and CAN vs. SB+RP-Met and CAN+RP-Met); and probability of PS $\times$ RP-Met supplementation interaction.

${ }^{4} 4 \% \mathrm{FCM}, \mathrm{kg} / \mathrm{d}=[0.4 \times$ milk yield $(\mathrm{kg} / \mathrm{d})]+[15 \times$ milk fat yield $(\mathrm{kg} / \mathrm{d})] ;$ Gaines and Davidson $(1923)$.

${ }^{5} \mathrm{ECM}, \mathrm{kg} / \mathrm{d}=[0.0752 \times$ milk yield $(\mathrm{kg} / \mathrm{d})]+[12.3 \times$ fat yield $(\mathrm{kg} / \mathrm{d})]+[6.56 \times \mathrm{SNF}(\mathrm{kg} / \mathrm{d})] ;$ Tyrrell and Reid $(1965)$.

particularly digestible His and Met, was a better match to that of GFP than SBM.

Feed efficiencies, expressed as milk yield/DMI, $4 \%$ FCM yield/DMI, and ECM yield/DMI, were not affected by protein source (Table 3). Likewise, no protein source effects were observed for concentrations of milk fat and true protein (Table 3). However, milk lactose $(P$ $=0.05)$ and $\operatorname{SNF}(P=0.02)$ concentrations increased, whereas milk TS $(P=0.09)$ content tended to increase in cows fed $\mathrm{SB}$ and $\mathrm{SB}+\mathrm{RP}-$ Met rather than $\mathrm{CAN}$ and CAN+RP-Met diets (Table 3). Increased milk concentrations of lactose, SNF, and TS were likely caused by a dilution effect due to reduced milk volume in cows receiving diets containing SBM. Yields of milk fat, true protein, SNF, and TS followed milk yield and were all greater $(P \leq 0.01)$ with feeding $\mathrm{CAN}$ and $\mathrm{CAN}+\mathrm{RP}$ Met versus $\mathrm{SB}$ and $\mathrm{SB}+\mathrm{RP}-$ Met diets. Improved milk true protein synthesis in cows fed $\mathrm{CM}$ in the present study agrees with Broderick et al. (2015) and Gidlund et al. (2015), but not with Brito and Broderick (2007), Maxin et al. (2013a), and Paula et al. (2018). When data from several published studies were used in the meta-analyses of Huhtanen et al. (2011) and Martineau et al. (2013), CM consistently increased milk protein yield over SBM. The increases in milk component yields observed for cows fed diets containing CM herein were likely associated with elevated DMI, which, in turn, may have increased in response to more energy demand to produce milk, as previously discussed ("pull effect"). The increased DMI in CM- versus SBM-fed cows, and its consequent influence on animal production, is a confounding effect that should be acknowledged when interpreting current and literature results.

A protein source effect $(P<0.01$; Table 3$)$ was observed for MUN concentration, with cows fed CAN and $\mathrm{CAN}+\mathrm{RP}-$ Met showing lower values $($ mean $=11.9$ $\mathrm{mg} / \mathrm{dL}$ ) than those offered SB and SB+RP-Met diets $($ mean $=12.8 \mathrm{mg} / \mathrm{dL})$. Inconsistent responses in MUN concentration have been found in individual studies that used SBM and CM. Although MUN concentration decreased with feeding CM in some studies (Maxin et al., 2013a; Broderick et al., 2015; Gidlund et al., 2015; Paula et al., 2018), no differences between SBM and CM were observed by others (Sánchez and Claypool, 1983; Brito and Broderick, 2007). However, collective study results from the meta-analysis of Martineau et al. (2014) showed that replacing protein sources, including SBM, with CM decreased MUN and PUN concentrations in dairy cows. Decreased MUN may be related to less ruminal degradability of CM compared 
with SBM. In fact, Maxin et al. (2013b) reported that the estimated in situ ruminal degradation of $\mathrm{CP}$ was lower for CM (47\%) than for SBM (58\%). Furthermore, previous researchers demonstrated that the ruminal concentrations of total free AA (Brito and Broderick, 2007), as well as those of $\mathrm{NH}_{3} \mathrm{~N}$ and branched-chain VFA (Broderick et al., 2015), were significantly lower in $\mathrm{CM}$ versus SBM. These results suggest that protein from $\mathrm{CM}$ was less degradable in the rumen than protein from SBM. The concentration of PUN followed that of MUN and decreased $(P<0.01)$ with feeding CAN and
$\mathrm{CAN}+\mathrm{RP}-\mathrm{Met}($ mean $=21.1 \mathrm{mg} / \mathrm{dL})$ rather than $\mathrm{SB}$ and SB+RP-Met $($ mean $=22.3 \mathrm{mg} / \mathrm{dL})$ diets $($ Table 3$)$. Lowered MUN and PUN concentrations, accompanied by increased milk true protein yield in cows fed diets containing CM, suggest improved whole-body $\mathrm{N}$ use efficiency. No treatment effects were observed for milk SCC, as shown in Table 3.

Plasma AA and Mammary Extraction of AA. Treatment effects on the concentrations of plasma AA from CGV blood vessels are shown in Table 4. Except for the CGV plasma concentration of Arg, all remain-

Table 4. Least squares means for the coccygeal vessel plasma concentrations of individual EAA and NEAA, histidine-containing metabolites (3-methylhistidine and carnosine), and total AA in lactating dairy cows fed diets containing finely ground field pea plus soybean meal or canola meal, with or without rumen-protected Met (RP-Met) ${ }^{1}$

\begin{tabular}{|c|c|c|c|c|c|c|c|c|}
\hline \multirow[b]{2}{*}{ AA and metabolites, $\mu M$} & \multicolumn{4}{|c|}{$\operatorname{Diet}^{2}$} & \multirow[b]{2}{*}{ SEM } & \multicolumn{3}{|c|}{$P$-value ${ }^{3}$} \\
\hline & $\mathrm{SB}$ & $\mathrm{SB}+\mathrm{RP}-\mathrm{Met}$ & CAN & $\mathrm{CAN}+\mathrm{RP}-\mathrm{Met}$ & & $\mathrm{PS}$ & RP-Met & $\mathrm{PS} \times \mathrm{RP}-\mathrm{Met}$ \\
\hline \multicolumn{9}{|l|}{ EAA } \\
\hline Arg & 84.1 & 83.2 & 83.8 & 86.0 & 3.05 & 0.57 & 0.77 & 0.49 \\
\hline His & 62.4 & 57.9 & 62.0 & 64.0 & 2.89 & 0.09 & 0.46 & 0.05 \\
\hline Ile & 133 & 137 & 144 & 140 & 5.24 & 0.03 & 0.98 & 0.16 \\
\hline Leu & 153 & 149 & 162 & 159 & 6.71 & $<0.01$ & 0.35 & 0.84 \\
\hline Lys & 87.9 & 88.3 & 92.1 & 94.4 & 4.26 & 0.05 & 0.61 & 0.70 \\
\hline Met & 22.1 & 36.6 & 25.1 & 40.2 & 0.83 & $<0.01$ & $<0.01$ & 0.67 \\
\hline Phe & 44.1 & 43.5 & 45.7 & 46.7 & 1.23 & 0.01 & 0.81 & 0.39 \\
\hline Thr & 105 & 105 & 117 & 116 & 4.55 & $<0.01$ & 0.80 & 0.79 \\
\hline $\operatorname{Trp}$ & 37.7 & 37.6 & 40.7 & 41.3 & 1.04 & $<0.01$ & 0.74 & 0.62 \\
\hline Val & 274 & 272 & 302 & 297 & 10.7 & $<0.01$ & 0.52 & 0.76 \\
\hline \multicolumn{9}{|l|}{ NEAA } \\
\hline Ala & 271 & 277 & 284 & 288 & 7.69 & 0.03 & 0.35 & 0.81 \\
\hline Asn & 53.4 & 55.7 & 53.5 & 53.8 & 1.92 & 0.36 & 0.22 & 0.34 \\
\hline Asp & 3.52 & 2.88 & 3.57 & 3.44 & 0.54 & 0.52 & 0.42 & 0.60 \\
\hline Cit & 98.9 & 98.1 & 94.4 & 97.4 & 4.63 & 0.32 & 0.68 & 0.47 \\
\hline Cystathionine & 1.90 & 2.95 & 2.14 & 3.09 & 0.12 & 0.08 & $<0.01$ & 0.61 \\
\hline Cystine & 20.8 & 22.6 & 20.8 & 21.6 & 0.58 & 0.36 & 0.02 & 0.35 \\
\hline Glu & 40.5 & 40.2 & 42.5 & 39.7 & 1.52 & 0.54 & 0.18 & 0.26 \\
\hline Gln & 271 & 264 & 258 & 262 & 8.18 & 0.29 & 0.87 & 0.45 \\
\hline Gly & 312 & 305 & 299 & 287 & 10.7 & $<0.01$ & 0.08 & 0.61 \\
\hline Homocysteine & 3.01 & 2.95 & 2.88 & 3.24 & 0.26 & 0.44 & 0.14 & 0.05 \\
\hline Orn & 51.5 & 52.1 & 52.3 & 53.9 & 2.21 & 0.33 & 0.38 & 0.71 \\
\hline Pro & 90.2 & 89.2 & 87.7 & 86.1 & 3.09 & 0.08 & 0.43 & 0.84 \\
\hline Ser & 88.8 & 88.2 & 85.9 & 81.8 & 2.83 & $<0.01$ & 0.17 & 0.30 \\
\hline Tau & 53.5 & 55.6 & 53.0 & 63.9 & 2.62 & 0.04 & $<0.01$ & 0.02 \\
\hline Tyr & 43.6 & 45.0 & 48.4 & 50.2 & 1.70 & $<0.01$ & 0.22 & 0.87 \\
\hline 3-Methylhistidine & 3.90 & 3.53 & 3.72 & 3.78 & 0.20 & 0.79 & 0.23 & 0.09 \\
\hline Carnosine & 24.1 & 23.4 & 22.7 & 24.6 & 1.08 & 0.90 & 0.54 & 0.18 \\
\hline Total branched-chain $\mathrm{AA}^{4}$ & 559 & 557 & 608 & 596 & 21.5 & $<0.01$ & 0.54 & 0.65 \\
\hline Total EAA & 1,002 & 1,009 & 1,075 & 1,084 & 32.4 & $<0.01$ & 0.67 & 0.95 \\
\hline Total urea cycle $\mathrm{AA}^{5}$ & 235 & 233 & 230 & 237 & 7.68 & 0.98 & 0.56 & 0.43 \\
\hline Total sulfur $\mathrm{AA}^{6}$ & 96.4 & 115 & 98.9 & 126 & 2.77 & $<0.01$ & $<0.01$ & 0.07 \\
\hline Total NEAA & 1,407 & 1,406 & 1,392 & 1,399 & 24.5 & 0.54 & 0.85 & 0.82 \\
\hline Total $\mathrm{AA}^{7}$ & 2,138 & 2,138 & 2,183 & 2,195 & 44.5 & 0.08 & 0.83 & 0.82 \\
\hline
\end{tabular}

${ }^{1}$ RP-Met is Smartamine M (Adisseo USA Inc., Alpharetta, GA) supplemented at 0.095\% (27 g/d) of diet DM.

${ }^{2} \mathrm{SB}=$ soybean meal plus finely ground field pea; $\mathrm{SB}+\mathrm{RP}-\mathrm{Met}=$ soybean meal plus finely ground field pea supplemented with RP-Met; CAN = canola meal plus finely ground field pea; and CAN+RP-Met = canola meal plus finely ground field pea supplemented with RP-Met.

${ }^{3}$ Probability of protein source (PS) main effect (SB and SB+RP-Met vs. CAN and CAN+RP-Met); probability of RP-Met supplementation main effect (SB and CAN vs. SB+RP-Met and CAN+RP-Met); and probability of PS $\times$ RP-Met supplementation interaction.

${ }^{4}$ Total branched-chain AA $=\mathrm{Ile}+\mathrm{Leu}+$ Val

${ }^{5}$ Total urea cycle $\mathrm{AA}=\mathrm{Arg}+\mathrm{Cit}+$ Orn.

${ }^{6}$ Total sulfur AA $=$ Met + cystathionine + cystine + homocysteine + Tau.

${ }^{7}$ Total $\mathrm{AA}=$ total $\mathrm{EAA}+$ total NEAA. 
ing individual EAA increased $(P \leq 0.05)$ in cows fed $\mathrm{CAN}$ and $\mathrm{CAN}+\mathrm{RP}-\mathrm{Met}$ versus $\mathrm{SB}$ and $\mathrm{SB}+\mathrm{RP}-\mathrm{Met}$ diets. Elevated concentrations of most individual EAA in cows fed CM diets agree with results from Martineau et al. (2014), who reported positive responses for all EAA when CM replaced other protein sources, including SBM. However, Maxin et al. (2013a) showed that only Met and Val increased with feeding CM rather than SBM. On the other hand, Gidlund et al. (2015) demonstrated that, compared with CM, cows fed SBM had increased Phe concentration in plasma, which was the only EAA affected by treatments. It is possible that increased intakes of DM and OM (Table 6) in CMversus SBM-fed cows explain the improvement of CGV plasma EAA in our study. Alternatively, Brito et al. (2007) observed that more protein from CM escaped ruminal degradation than that from SBM, suggesting increased amounts of EAA available to be absorbed in the small intestine.
A protein source $\times$ RP-Met interaction effect $(P=$ 0.05) was observed for the CGV plasma His concentration. Whereas His concentration decreased with feeding $\mathrm{SB}+\mathrm{RP}-\mathrm{Met}$, it increased in the $\mathrm{CAN}+\mathrm{RP}-$ Met diet. Pereira et al. (2017) reported that adding RP-ML to a diet containing (DM basis) 25\% GFP decreased the plasma concentration of His, compared with GFP without RP-ML. Patton et al. (2015) demonstrated that increased postruminal supply of Met was more potent than that of Lys, leading to a decrease in all EAA concentrations in plasma except Arg and Lys. Our current results showed that CM not only prevented a drop but also increased circulating His in dairy cows fed CAN+RP-Met, suggesting improved supply of digestible His or that the digestible profile of EAA in CM better matched that of GFP compared with SBM.

Protein source effects $(P \leq 0.04)$ were found for the CGV plasma concentrations of the individual NEAA Ala, Gly, Ser, and Tyr, and trends $(P=0.08)$

Table 5. Least squares means for the subcutaneous abdominal vein (mammary vein) plasma concentrations of individual EAA, total branchedchain AA, and total EAA, and mammary extraction efficiency of EAA in lactating dairy cows fed diets containing finely ground field pea plus soybean meal or canola meal, with or without rumen-protected Met (RP-Met) ${ }^{1}$

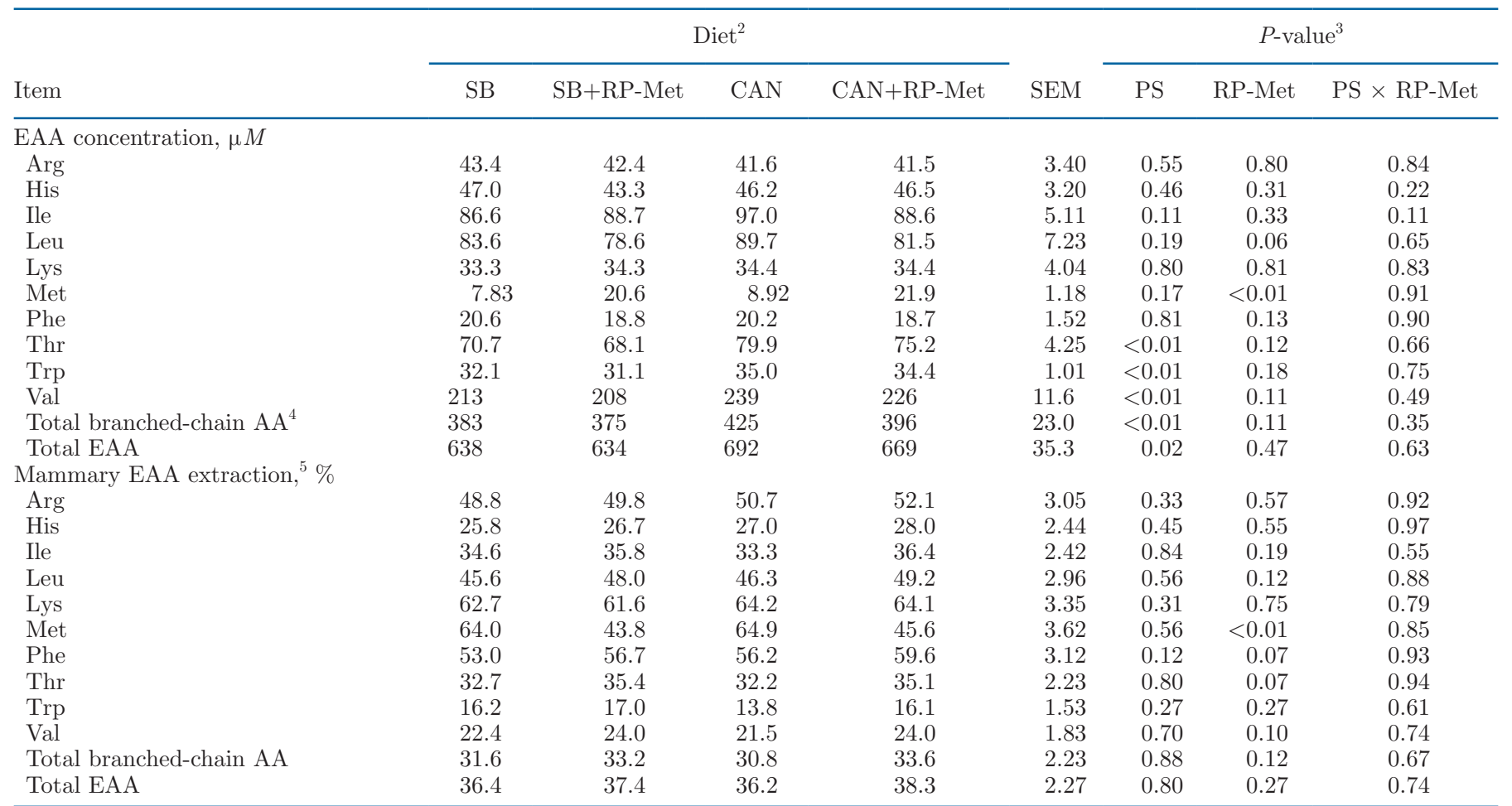

${ }^{1}$ RP-Met is Smartamine M (Adisseo USA Inc., Alpharetta, GA) supplemented at 0.095\% (27 g/d) of diet DM.

${ }^{2} \mathrm{SB}=$ soybean meal plus finely ground field pea; $\mathrm{SB}+\mathrm{RP}-\mathrm{Met}=$ soybean meal plus finely ground field pea supplemented with RP-Met; CAN = canola meal plus finely ground field pea; and CAN+RP-Met = canola meal plus finely ground field pea supplemented with RP-Met.

${ }^{3}$ Probability of protein source (PS) main effect (SB and SB+RP-Met vs. CAN and CAN+RP-Met); probability of RP-Met supplementation main effect (SB and CAN vs. SB+RP-Met and CAN+RP-Met); and probability of PS $\times$ RP-Met supplementation interaction.

${ }^{4}$ Total branched-chain AA $=$ Ile + Leu + Val.

${ }^{5}$ Mammary EAA extraction $(\%)=[\operatorname{coccygeal}$ blood plasma EAA $(\mu M)-$ mammary vein plasma EAA $(\mu M)] / \operatorname{coccygeal}$ plasma EAA $(\mu M) \times$ 100. Concentrations of EAA in coccygeal blood vessel plasma are presented in Table 4. 
for cystathionine and Pro (Table 4). Although CGV plasma concentrations of Ala and Tyr increased, those of Gly and Ser decreased in dairy cows fed CAN and $\mathrm{CAN}+\mathrm{RP}-\mathrm{Met}$ versus $\mathrm{SB}$ and $\mathrm{SB}+\mathrm{RP}-\mathrm{Met}$ diets. According to Miettinen and Huhtanen (1997), plasma concentrations of some NEAA, such as Gln, Gly, and Ser, can decrease due to their utilization for hepatic gluconeogenesis. In fact, both Gly and Ser concentrations in CGV plasma decreased with feeding diets containing $\mathrm{CM}$ in the present experiment, suggesting that these 2 NEAA may have been used for synthesis of glucose in the liver. Protein source $\times$ RP-Met interaction effects were observed for the concentrations of Tau $(P=0.02)$ and homocysteine $(P=0.05)$ in CGV plasma, with RP-Met being more effective to increase these NEAA when supplemented to CM than SBM (Table 4). Both interactions are indicative of a synergistic effect between RP-Met and CM to elevate Tau and homocysteine, as the CGV plasma concentration of Met was greater $(P<0.01)$ in cows fed diets containing CM versus SBM. Methionine is involved in transmethylation and transsulfuration reactions of the 1-carbon metabolism cycle, leading to the formation of homocysteine, which is converted to cystathionine that is used to produce Gly, a precursor of Tau (Baker, 2006; Ripps and Shen, 2012).

Table 6. Least squares means for intake and apparent total-tract digestibility of nutrients, $\mathrm{N}$ balance, and urinary excretion of nitrogenous metabolites in lactating dairy cows fed diets containing finely ground field pea plus soybean meal or canola meal, with or without rumenprotected Met (RP-Met) ${ }^{1}$

\begin{tabular}{|c|c|c|c|c|c|c|c|c|}
\hline \multirow[b]{2}{*}{ Item } & \multicolumn{4}{|c|}{ Diet $^{2}$} & \multirow[b]{2}{*}{ SEM } & \multicolumn{3}{|c|}{$P$-value ${ }^{3}$} \\
\hline & $\mathrm{SB}$ & $\mathrm{SB}+\mathrm{RP}-\mathrm{Met}$ & $\mathrm{CAN}$ & $\mathrm{CAN}+\mathrm{RP}-\mathrm{Met}$ & & PS & RP-Met & $\mathrm{PS} \times \mathrm{RP}-\mathrm{Met}$ \\
\hline \multicolumn{9}{|l|}{ Nutrient intake } \\
\hline $\mathrm{DM}, \mathrm{kg} / \mathrm{d}$ & 28.1 & 27.8 & 28.6 & 29.1 & 0.77 & $<0.01$ & 0.81 & 0.28 \\
\hline $\mathrm{OM}, \mathrm{kg} / \mathrm{d}$ & 26.2 & 25.9 & 26.6 & 27.0 & 0.72 & 0.01 & 0.81 & 0.28 \\
\hline $\mathrm{N}, \mathrm{g} / \mathrm{d}$ & 775 & 769 & 769 & 781 & 20.9 & 0.73 & 0.77 & 0.28 \\
\hline aNDFom, ${ }^{4} \mathrm{~kg} / \mathrm{d}$ & 7.15 & 7.07 & 8.16 & 8.27 & 0.21 & $<0.01$ & 0.90 & 0.33 \\
\hline $\mathrm{ADF}, \mathrm{kg} / \mathrm{d}$ & 4.65 & 4.59 & 5.35 & 5.42 & 0.14 & $<0.01$ & 0.89 & 0.32 \\
\hline Starch, kg/d & 9.53 & 9.43 & 9.18 & 9.33 & 0.25 & 0.04 & 0.78 & 0.24 \\
\hline \multicolumn{9}{|l|}{ Apparent total-tract digestibility } \\
\hline DM, $\%$ of DMI & 75.7 & 75.8 & 72.6 & 72.8 & 0.75 & $<0.01$ & 0.79 & 0.99 \\
\hline OM, $\%$ of OM intake & 76.8 & 77.0 & 73.9 & 74.1 & 0.71 & $<0.01$ & 0.77 & 0.98 \\
\hline $\mathrm{N}, \%$ of $\mathrm{N}$ intake & 73.0 & 73.4 & 69.5 & 70.2 & 0.96 & $<0.01$ & 0.55 & 0.84 \\
\hline aNDFom, $\%$ of aNDFom intake & 52.2 & 51.9 & 50.1 & 49.2 & 1.34 & 0.08 & 0.65 & 0.83 \\
\hline $\mathrm{ADF}, \%$ of $\mathrm{ADF}$ intake & 59.1 & 58.8 & 54.1 & 52.9 & 1.26 & $<0.01$ & 0.54 & 0.73 \\
\hline Starch, $\%$ of starch intake & 97.2 & 96.6 & 96.2 & 96.7 & 0.40 & 0.15 & 0.83 & 0.15 \\
\hline \multicolumn{9}{|l|}{$\mathrm{N}$ output and retained } \\
\hline Urinary creatinine, $\mathrm{m} M$ & 6.17 & 6.32 & 7.21 & 7.50 & 0.33 & $<0.01$ & 0.38 & 0.78 \\
\hline Urinary volume ${ }^{5} \mathrm{~L} / \mathrm{d}$ & 31.8 & 31.7 & 28.3 & 27.0 & 1.47 & $<0.01$ & 0.54 & 0.60 \\
\hline Milk N, g/d & 202 & 205 & 210 & 214 & 9.20 & $<0.01$ & 0.13 & 0.74 \\
\hline Urinary $\mathrm{N}, \mathrm{g} / \mathrm{d}$ & 297 & 283 & 275 & 281 & 12.4 & 0.14 & 0.64 & 0.24 \\
\hline Fecal N, g/d & 211 & 205 & 235 & 234 & 11.3 & $<0.01$ & 0.66 & 0.74 \\
\hline Manure N, g/d & 508 & 488 & 510 & 515 & 17.9 & 0.21 & 0.52 & 0.26 \\
\hline Retained N, g/d & 65.2 & 75.1 & 50.0 & 51.8 & 14.0 & 0.11 & 0.62 & 0.73 \\
\hline Milk N, $\%$ of $\mathrm{N}$ intake & 26.1 & 26.8 & 27.2 & 27.5 & 1.00 & $<0.01$ & 0.16 & 0.54 \\
\hline Urinary $\mathrm{N}, \%$ of $\mathrm{N}$ intake & 38.5 & 37.1 & 35.8 & 36.2 & 1.64 & 0.11 & 0.64 & 0.43 \\
\hline Fecal N, \% of $\mathrm{N}$ intake & 27.0 & 26.6 & 30.5 & 29.8 & 0.96 & $<0.01$ & 0.55 & 0.84 \\
\hline Manure $\mathrm{N}, \%$ of $\mathrm{N}$ intake & 65.5 & 63.7 & 66.3 & 66.0 & 1.74 & 0.28 & 0.46 & 0.63 \\
\hline Retained N, \% of $\mathrm{N}$ intake & 8.43 & 9.51 & 6.45 & 6.55 & 1.78 & 0.10 & 0.69 & 0.75 \\
\hline \multicolumn{9}{|l|}{ Urinary nitrogenous metabolites } \\
\hline $\mathrm{NH}_{3} \mathrm{~N}, \mathrm{~g} / \mathrm{d}$ & 1.92 & 1.91 & 1.56 & 1.49 & 0.22 & 0.05 & 0.85 & 0.86 \\
\hline $\mathrm{NH}_{3} \mathrm{~N}, \%$ of urinary $\mathrm{N}$ & 0.69 & 0.71 & 0.60 & 0.56 & 0.09 & 0.08 & 0.91 & 0.65 \\
\hline $\mathrm{NH}_{3} \mathrm{~N}, \%$ of $\mathrm{N}$ intake & 0.25 & 0.26 & 0.21 & 0.19 & 0.03 & 0.05 & 0.86 & 0.67 \\
\hline Urea $\mathrm{N}, \mathrm{g} / \mathrm{d}$ & 171 & 166 & 151 & 146 & 9.52 & $<0.01$ & 0.43 & 0.98 \\
\hline Urea $\mathrm{N}, \%$ of urinary $\mathrm{N}$ & 57.8 & 58.4 & 53.9 & 52.0 & 2.11 & $<0.01$ & 0.74 & 0.52 \\
\hline Urea $\mathrm{N}, \%$ of $\mathrm{N}$ intake & 22.0 & 21.7 & 19.9 & 18.9 & 1.30 & $<0.01$ & 0.40 & 0.69 \\
\hline Allantoin, mmol/d & 559 & 567 & 557 & 596 & 37.2 & 0.72 & 0.54 & 0.68 \\
\hline
\end{tabular}

${ }^{1}$ RP-Met is Smartamine M (Adisseo USA Inc., Alpharetta, GA) supplemented at 0.095\% (27 g/d) of diet DM.

${ }^{2} \mathrm{SB}=$ soybean meal plus finely ground field pea; $\mathrm{SB}+\mathrm{RP}-\mathrm{Met}=$ soybean meal plus finely ground field pea supplemented with RP-Met; CAN = canola meal plus finely ground field pea; and CAN+RP-Met = canola meal plus finely ground field pea supplemented with RP-Met.

${ }^{3}$ Probability of protein source (PS) main effect (SB and SB+RP-Met vs. CAN and CAN+RP-Met); probability of RP-Met supplementation main effect (SB and CAN vs. SB+RP-Met and CAN+RP-Met); and probability of PS $\times$ RP-Met supplementation interaction.

${ }^{4}$ aNDFom $=$ amylase-treated, exclusive of ash NDF.

${ }^{5}$ Estimated from the urinary concentration of creatinine, assuming a constant creatinine excretion rate of $29 \mathrm{mg} / \mathrm{kg}$ of BW (Valadares et al., 1999). 
Protein source effects $(P<0.01)$ were also found for the CGV plasma concentrations of total branched-chain AA, total sulfur AA, and total EAA, with cows offered $\mathrm{CAN}$ and $\mathrm{CAN}+\mathrm{RP}-\mathrm{Met}$ showing greater values than those receiving SB and SB+RP-Met (Table 4). These results are explained by increased CGV plasma concentrations of most individual EAA, including Ile, Leu, Val, and Met, in cows fed diets in which CM replaced SBM, corroborating data from Martineau et al. (2014).

Treatment effects on the plasma concentrations of individual EAA and NEAA from the MV are shown in Table 5 and Supplemental Table S1 (https://doi.org/10 $.3168 /$ jds.2019-17186), respectively. Protein source effects $(P<0.01)$ were observed for the MV plasma concentrations of Thr, Trp, and Val, which all increased in cows offered CAN and CAN+RP-Met versus SB and $\mathrm{SB}+\mathrm{RP}-\mathrm{Met}$ diets. The CGV plasma concentrations of all EAA (except Arg) also increased with feeding diets in which CM substituted SBM, suggesting that Thr, Trp, and Val were less utilized by mammary tissues. The MV plasma concentrations of total branched-chain AA $(P<0.01)$ and total EAA $(P=0.02)$ were greater in CAN and CAN+RP-Met than in SB and SB+RPMet diets (Table 5), in agreement with the CGV plasma results discussed previously.

The MV plasma concentrations of Asn $(P=0.03)$, Gln $(P<0.01)$, and Ser $(P<0.01)$ decreased, and those of Gly $(P=0.10)$ and Pro $(P=0.06)$ tended to be lower in cows fed CAN and CAN+RP-Met versus $\mathrm{SB}$ and SB+RP-Met diets (Supplemental Table S1). In contrast, the concentration of Ala in MV plasma was greater $(P=0.05)$ in diets containing $\mathrm{CM}$ rather than SBM (Supplemental Table S1), which is consistent with the concentration of Ala in CGV plasma (Table 4). The observed drop in the MV concentrations of Asn, Gln, Ser, Gly, and Pro when CM replaced SBM may reflect their increased utilization for hepatic gluconeogenesis (Miettinen and Huhtanen, 1997).

Protein source $\times$ RP-Met interactions were observed for the MV plasma concentrations of Asp $(P=0.03)$ and cystine (the oxidized form of Cys; $P=0.04$ ), as shown in Supplemental Table S1. Whereas feeding SB+RP-Met decreased Asp concentration by 46\%, Asp increased by $11 \%$ in cows receiving CAN+RP-Met. We do not have a straightforward explanation for this interaction, although it suggests that Asp may have been catabolized more intensively by mammary cells in cows fed SB+RP-Met. The concentration of cystine in the MV plasma increased by $10.1 \%$ in the SB+RP-Met diet, but it decreased slightly with feeding $\mathrm{CAN}+\mathrm{RP}-$ Met. A positive effect of RP-Met on sulfur-containing AA is expected, implying that this minor drop of cystine was caused by a greater supply of Met from CM than SBM, which offset the contribution of Met from RP-Met.

Treatment effects on the extraction of individual EAA and NEAA by the mammary gland using the $\mathrm{A}-\mathrm{V}$ difference method are presented in Table 5 and Supplemental Table S1, respectively. The AA extraction efficiency calculation has been used for ranking limiting AA in descending order, so that the AA with the greatest extraction efficiency is considered the first limiting AA (Mulrooney et al., 2009; Mjoun et al., 2010). Blood sampling from the CGV (either arterial or venous) represents the arterial side in the $\mathrm{A}-\mathrm{V}$ difference method (Doepel and Lapierre, 2010; Mjoun et al., 2010; Paz and Kononoff, 2014). The A-V differences in chemical composition across the CGV are assumed to be negligible, implying that the nutrient profile of either venous or arterial CGV blood are representative of the mammary gland arterial supply (Emery et al.,1965; Cant et al.,1993). Zhang et al. (2016) concluded that, except for Asp, Thr, and Glu, CGV blood sampling can replace sampling from the external pudic artery, as no differences between blood sampling sites were detected for the remaining AA in lactating dairy cows. Nevertheless, Lapierre et al. (2012) showed that pooling of plasma samples, often done to reduce analytical costs when using the $\mathrm{A}-\mathrm{V}$ difference method, increases variation and should be avoided if possible. In addition, Paz and Kononoff (2014) observed a diurnal effect of sampling time on the extraction of some EAA, including Leu, Met, Phe, and Thr. Thus, our mammary AA extraction efficiency data, which were obtained using pooled plasma samples collected during the morning feeding cycle, should be interpreted cautiously.

Protein source did not affect the mammary extraction efficiency of any individual EAA using the A-V difference method (Table 5). However, Lys (mean = $63.2 \%)$ followed by Phe $($ mean $=56.4 \%)$ were the EAA most extracted by the mammary gland, suggesting that they were the overall first and second limiting AA, respectively. In diets not supplemented with RP-Met (i.e., SB and CAN), Met was the EAA with the greatest extraction efficiency (mean $=64.5 \%$ ) by mammary tissues, implying that Met was the first limiting AA in these 2 diets. Despite the greater concentration of Lys in GFP than in SBM or CM, and equivalent Phe contents among these 3 feedstuffs (Table 1), GFP is rich in soluble $\mathrm{CP}$, known to be rapidly degraded in the rumen. In addition, SBM, CM, and GFP are poor to moderate sources of Met (Table 1). Regarding the mammary extraction efficiency of NEAA, cows fed CAN and $\mathrm{CAN}+\mathrm{RP}-\mathrm{Met}$ had greater $(P \leq 0.05)$ extractions of Asn, Gln, and Ser than those fed SB and 
$\mathrm{SB}+\mathrm{RP}-\mathrm{Met}$, suggesting increased use of these AA for gluconeogenesis, as discussed above.

Intake, Digestibility, and $N$ Balance. Treatment effects on intake and apparent total-tract digestibility of nutrients and $\mathrm{N}$ balance are presented in Table 6 . Intakes of $\mathrm{OM}$, aNDFom, and $\mathrm{ADF}$ followed DMI and were all greater $(P \leq 0.01)$ in cows fed CAN and CAN+RP-Met versus SB and SB+RP-Met diets. Dietary concentrations of aNDFom and ADF were greater in diets containing CM compared with those containing SBM (Table 2), which is consistent with the observed increase in fiber intake. In contrast, starch intake was reduced $(P=0.04)$ by $3.4 \%$ with diets containing $\mathrm{CM}$, due to the 2.2-percentage-unit-lower dietary starch concentration relative to the SBM counterparts (Table 2 ). No protein source effect was observed for $\mathrm{N}$ intake (Table 6).

Fecal and urinary samples were collected 3 times daily $(0700 \mathrm{~h}, 1500 \mathrm{~h}$, and $2300 \mathrm{~h})$ over $2 \mathrm{~d}$ in the present experiment. It should be noted that this sampling protocol did not cover a diurnal feeding cycle, and 2 d was likely too short to account for the variability in DMI. Recent research revealed that approximatively 6 time points appear to be required for estimating fecal output of DM and urinary volume when using the fecal grab and spot urine sampling protocols, respectively, in dairy cows (Morris et al., 2018; Lee et al., 2019). Therefore, our apparent total-tract digestibility and urinary excretion data should be interpreted cautiously.

Protein source effects $(P<0.01)$ were found for the apparent total-tract digestibilities of DM, OM, N, and $\mathrm{ADF}$, with cows fed SB and SB+RP-Met showing greater values compared with those offered CAN and CAN+RP-Met diets (Table 6). Moreover, the apparent total-tract digestibility of aNDFom tended $(P=0.08)$ to increase with feeding diets containing SBM versus $\mathrm{CM}$, whereas starch digestibility did not change. The concentration of ADL was 31-fold lower in SBM than in CM (Table 1), in line with the elevated total-tract fiber digestibility in the SB and SB+RP-Met diets. Further, protein from SBM appears to be more degradable in the rumen than that from CM (Maxin et al., 2013b), which may explain the improvement in total-tract $\mathrm{N}$ digestibility in SBM-fed cows, as the dietary concentrations of neutral and acid detergent insoluble $\mathrm{CP}$ were similar across diets (Table 2). Although Brito and Broderick (2007) reported no differences in the apparent totaltract digestibilities of $\mathrm{DM}, \mathrm{OM}, \mathrm{N}$, and $\mathrm{ADF}$ between SBM and CM, Paula et al. (2018) observed increased digestibilities for DM, OM, NDF, and ADF when SBM was substituted by CM. Huhtanen et al. (2011) showed through their meta-analysis that the apparent totaltract digestibilities of $\mathrm{OM}$ and $\mathrm{CP}$ were similar in $\mathrm{SBM}$ versus CM diets. These inconsistent responses in totaltract nutrient digestibility across studies may reflect differences in the ingredient and chemical composition of the basal diets, variation in SBM and CM nutritional profile, experimental design (changeover vs. continuous), and animal factors (e.g., DIM, DMI, production level). Despite decreased digestibility in diets containing $\mathrm{CM}$ in the present study, yields of milk and milk fat and true protein increased, suggesting that elevated DMI with feeding CAN and CAN+RP-Met offset energy losses through depressed nutrient digestibility in the gastrointestinal tract.

Although the urinary concentration of creatinine decreased $(-15 \% ; P<0.001)$, urinary volume increased $(+14.8 \% ; P<0.001)$ in cows fed SB and SB+RP-Met versus $\mathrm{CAN}$ and $\mathrm{CAN}+\mathrm{RP}-\mathrm{Met}$ diets (Table 6). Intake of $\mathrm{K}$ was $6.6 \%$ greater in SBM- than in CM-containing diets (data not shown), consistent with the observed increase in urinary volume. In fact, Eriksson and Rustas (2014) reported a positive linear relationship between $\mathrm{K}$ intake and urinary volume in lactating dairy cows $\left(0.058 \mathrm{~kg}\right.$ of urine $/ \mathrm{g}$ of $\mathrm{K}$ intake; $\mathrm{R}^{2}=0.97$; no intercept). However, using the equation of Eriksson and Rustas (2014) to predict the urinary volume of cows used in our study resulted in a mean difference of $1.31 \mathrm{~kg} / \mathrm{d}$ between treatments and not $4.15 \mathrm{~kg} / \mathrm{d}$, as reported in Table 6, suggesting the involvement of unknown factors.

Both milk $\mathrm{N}$ and fecal $\mathrm{N}$ outputs increased $(P<$ 0.01; Table 6) with feeding CAN and CAN+RP-Met rather than SB and SB+RP-Met. In contrast, no protein source effects were observed for the outputs of $\mathrm{N}$ in urine and manure (fecal $\mathrm{N}$ plus urinary $\mathrm{N}$ ) or for retained $\mathrm{N}$ (Table 6). However, milk $\mathrm{N}$ efficiency (i.e., milk $\mathrm{N} / \mathrm{N}$ intake) was greater $(P<0.01)$ when $\mathrm{CM}$ $($ mean $=27.4 \%)$ replaced SBM $($ mean $=26.5 \%)$ in the experimental diets (Table 6). Broderick et al. (2015) also observed greater milk $\mathrm{N}$ efficiency in dairy cows offered CM than in those offered SBM. Enhanced milk $\mathrm{N}$ efficiency with the substitution of SBM by CM suggests better $\mathrm{N}$ utilization, which may be linked to a greater supply of EAA or to an improvement in the duodenal profile of digestible His, Lys, and Met relative to milk protein synthesis requirements. Fecal $\mathrm{N}$ excretion, expressed as a proportion of $\mathrm{N}$ intake, was greater $(P<0.01)$ in CM- than in SBM-containing diets, due to decreased apparent total-tract $\mathrm{N}$ digestibility.

Retained $\mathrm{N}$ (\% of $\mathrm{N}$ intake) tended $(P=0.10)$ to be lower in cows receiving diets with CM versus SBM, mostly caused by increased fecal $\mathrm{N}$ excretion in CM-fed cows (Table 6). However, protein source did not affect the proportion of urinary $\mathrm{N}$ and manure $\mathrm{N}$ excretion in relation to $\mathrm{N}$ intake, as shown in Table 6. Similarly, 
the amount of retained $\mathrm{N}$ was not affected by protein source or by RP-Met supplementation (Table 6) and averaged $61 \mathrm{~g} / \mathrm{d}$ across diets. If body tissues contain $17 \%$ protein (NRC, 2001), $61 \mathrm{~g} / \mathrm{d}$ of retained $\mathrm{N}$ would result in a BW gain of $2.24 \mathrm{~kg} / \mathrm{d}[(61 \times 6.25) \div 0.17]$. This retained $\mathrm{N}$ value is unrealistic for mid-lactation dairy cows producing an average of $39.7 \mathrm{~kg}$ of milk daily (Table 3), and data should be interpreted cautiously. In a literature review of 35 published $\mathrm{N}$ balance experiments (125 diets) conducted with lactating dairy cows, Spanghero and Kowalski (1997) reported an average of $39 \mathrm{~g} / \mathrm{d}$ of retained $\mathrm{N}$ and a wide range from -57 to $205 \mathrm{~g} / \mathrm{d}$. Therefore, retained $\mathrm{N}$ appears to be systematically overestimated, not only in studies with lactating dairy cows (Spanghero and Kowalski, 1997) but also in highly controlled experiments using human subjects (Tomé and Bos, 2000). Possible sources of errors leading to questionable retained $\mathrm{N}$ values include (1) volatile $\mathrm{N}$ losses from feces and urine, (2) sample processing methods (e.g., oven-drying vs. lyophilization), (3) discrepancies in milk $\mathrm{N}$ analysis between the Kjeldahl method and infrared spectroscopy, (4) N losses through skin (urea $\mathrm{N}$ ) and expired air $\left(\mathrm{NH}_{3} \mathrm{~N}\right)$, and (5) nitrate present in feeds and urine, which is not detected by the Kjeldahl technique (Spanghero and Kowalski, 1997; Tomé and Bos, 2000; Morris et al., 2019).

Excretion of $\mathrm{NH}_{3} \mathrm{~N}$ and urea $\mathrm{N}$ in urine, expressed in grams per day or as a proportion of $\mathrm{N}$ intake, decreased $(P \leq 0.05)$ with feeding $\mathrm{CAN}$ and $\mathrm{CAN}+\mathrm{RP}-$ Met versus $\mathrm{SB}$ and $\mathrm{SB}+\mathrm{RP}-\mathrm{Met}$ diets (Table 6). In addition, excretion of $\mathrm{NH}_{3} \mathrm{~N}$ and urea $\mathrm{N}$, as a proportion of total urinary $\mathrm{N}$ excretion, either tended to decrease $(P=0.08)$ or decreased $(P<0.01)$, respectively, in cows fed CM- rather than SBM-containing diets (Table 6). Maxin et al. (2013a) also observed a reduction in urinary excretion of urea $\mathrm{N}$, as a proportion of total $\mathrm{N}$ output in urine, when CM replaced SBM in diets of lactating dairy cows. These urinary $\mathrm{NH}_{3} \mathrm{~N}$ and urea $\mathrm{N}$ excretion results, together with decreased MUN and PUN concentrations in cows fed CAN and CAN+RPMet, suggest that protein from CM was less degradable in the rumen than that from SBM, leading to better $\mathrm{N}$ use efficiency. On average, urea $\mathrm{N}$ made up $55.5 \%$ of the total urinary $\mathrm{N}$ excretion in the present study (Table 6), which seems low for diets with $16.9 \% \mathrm{CP}$ (Table 2). However, the starch concentration of our diets averaged $34.8 \%$ (Table 2 ) and may have provided either an excess or a balanced supply of fermentable energy relative to RDP, thus favoring the conversion of $\mathrm{NH}_{3}$ to microbial protein at expense of urea formation in the liver. We demonstrated previously that the concentration of ruminal $\mathrm{NH}_{3} \mathrm{~N}$ in GFP diets with $15 \%$ $\mathrm{CP}$ and $31.7 \%$ starch was low $($ mean $=4.30 \mathrm{mg} / \mathrm{dL})$, resulting in urinary urea $\mathrm{N}$ excretion, as a proportion of total urinary $\mathrm{N}$ (mean $=54.9 \%$ ), comparable to that observed herein. Further, according to the NRC (2001), our diets were in negative MP balance (from -71 to $-340 \mathrm{~g} / \mathrm{d}$ for SBM- vs. CM-containing treatments, respectively; data not shown). Low-MP diets have been shown to reduce urinary urea $\mathrm{N}$ excretion (\% of total urinary N) below 55\% (Lee et al., 2012), particularly in cows fed CM versus SBM (Broderick et al., 2015). Protein source did not affect the urinary excretion of allantoin in the current experiment, suggesting no difference between SBM and CM on stimulating microbial protein synthesis in the rumen, which agrees with earlier research (Brito et al., 2007; Maxin et al., 2013a; Paula et al., 2018).

\section{Rumen-Protected Methionine Effects}

Production Responses and PUN. Intake of DM was not affected by RP-Met supplementation in the current study (Table 3), which agrees with previous research (Rogers et al., 1989; Piepenbrink et al., 1998; Leonardi et al., 2003; Broderick et al., 2008). In contrast, supplementation with RP-ML improved DMI by $1.8 \mathrm{~kg} / \mathrm{d}$ in the experiment of Broderick et al. (2015) without concomitant increases on yields of milk, ECM, or milk components. According to Broderick et al. (2015), it was unclear why RP-ML supplementation stimulated such a large increase in DMI, particularly because changes in DMI in response to RP-AA have been smaller and not consistent across studies (Lee et al., 2012; Zanton et al., 2014; Whitehouse et al., 2017).

Except for the milk concentrations of true protein $(P<0.01)$ and SNF $(P<0.01)$, which increased, and lactose content, which decreased $(P=0.04)$, no other variables presented in Table 3 were affected by RPMet supplementation. The lack of RP-Met effect on yields of milk and milk components suggests that SBM or CM blended with GFP likely met the requirements for digestible Met. In addition, RDP balance averaged $630 \mathrm{~g} / \mathrm{d}$ across diets (data not shown), indicating that supply of preformed AA, peptides, and $\mathrm{NH}_{3} \mathrm{~N}$ did not limit microbial protein synthesis in the rumen. Broderick et al. (2015) reported no effects of RP-ML on yields of milk and milk components in cows fed SBM or CM. However, Piepenbrink et al. (1998) observed increased milk protein yield in dairy cows fed CM plus RP-ML, compared with those offered CM without RPML supplementation.

Plasma $A A$ and Mammary Extraction of $A A$. Apart from the CGV plasma concentration of Met, which increased $(P<0.01)$ by $63 \%$ with feeding RPMet, no other changes in individual EAA were observed 
(Table 4). This elevated Met concentration in CGV plasma in response to RP-Met was expected and agrees with data published in the literature using lactating dairy cows fed GFP (Pereira et al., 2017). Piepenbrink et al. (1998) reported no changes in the plasma concentrations of Lys or Met in response to RP-ML supplementation to a CM diet; however, both Leu and Phe concentrations decreased with RP-ML, suggesting increased utilization of these 2 EAA (Piepenbrink et al., 1998). The CGV plasma concentrations of the NEAA cystathionine $(P<0.01)$ and cystine $(P=0.02)$, as well as total sulfur AA $(P<0.01)$, increased in response to RP-Met supplementation (Table 4 ). The positive effect of RP-Met on circulating cystathionine and cystine is not surprising, because of the involvement of Met in transmethylation and transsulfuration reactions of the 1-carbon metabolism that originate cystathionine and Cys (Baker, 2006).

Except for the concentration of Met in MV plasma, which increased $(P<0.01)$ by $154 \%$, and that of Leu, which tended $(P=0.06)$ to decrease by $7.6 \%$, no other changes in the concentrations of individual EAA were observed in response to RP-Met supplementation (Table 5). Cows fed SB+RP-Met and CAN+RP-Met had lower $(P<0.01)$ mammary extraction of Met, based on the A-V difference method, than those offered the SB and CAN diets (Table 5), which indicates improved Met status in animals supplemented with RP-Met. Piepenbrink et al. (1998) observed no effect of RP-ML supplementation to a CM diet on the mammary extractions of Met and Lys. In contrast, the mammary extraction of His decreased in cows receiving CM plus RP-ML in a study by Piepenbrink et al. (1998). The mammary extraction efficiencies of Phe, Thr, and Val tended $(P$ $\leq 0.10)$ to increase with RP-Met supplementation in the present study (Table 5). Note that according to the mammary extraction efficiency calculations, Lys, Phe, and Arg were ranked as the first, second, and third limiting AA, respectively, in diets supplemented with RPMet (Table 5). Piepenbrink et al. (1998) reported that Lys, Met, and Phe were considered the first 3 limiting AA, in this order, in cows offered CM plus RP-ML.

The MV plasma concentration of Ser decreased $(P$ $<0.01)$, whereas that of Gln $(P=0.08)$ and Gly $(P$ $=0.06)$ tended to decrease with RP-Met supplementation (Supplemental Table S1, https://doi.org/10.3168/ jds.2019-17186), indicative of mammary oxidation of these NEAA for energy use. The mammary extraction efficiencies of both Asn $(P=0.05)$ and Ser $(P<0.01)$, using the A-V difference approach, increased with RPMet supplementation also, implying that these 2 AA were catabolized for energy use in the mammary gland (Supplemental Table S1).
Intake, Digestibility, and $N$ Balance. No effect of RP-Met supplementation was observed for nutrient intake, apparent total-tract digestibility of nutrients, and urinary excretion of nitrogenous metabolites (Table 6). Supplementation of RP-ML to a diet containing GFP did not change intake or apparent total-tract digestibility of nutrients in our previous research (Pereira et al., 2017). However, RP-ML reduced the urinary excretion (grams per day and percent of $\mathrm{N}$ intake) of $\mathrm{NH}_{3} \mathrm{~N}$ and urea $\mathrm{N}$ in lactating dairy cows fed GFP (Pereira et al., 2017). The discrepancy between our 2 studies regarding the effect of rumen-protected AA supplementation on urinary excretion of $\mathrm{NH}_{3} \mathrm{~N}$ and urea $\mathrm{N}$ may be related to the improved digestible EAA profile when RP-ML was added to the GFP diet in the Pereira et al. (2017) study, which contained a low proportion of SBM $(2.4 \%$, DM basis). In the current experiment, SBM (11\%) was fed in a greater amount, likely resulting in a digestible EAA profile that better matched that of GFP, offsetting the contribution of RP-Met. In contrast, Broderick et al. (2015) reported increased urinary outputs of total $\mathrm{N}$ and urea $\mathrm{N}$, possibly because the extra $\mathrm{N}$ intake from RP-ML in diets with SBM or CM contributed to the blood urea pool, as neither milk yield nor milk true protein secretion was affected by RP-ML supplementation.

\section{CONCLUSIONS}

Intake of DM, as well as yields of milk and milk fat and true protein, milk $\mathrm{N}$ efficiency, and concentrations of all EAA (except Arg) in blood plasma collected from the coccygeal vessels increased in dairy cows fed diets containing CM plus GFP versus SBM plus GFP. In addition, concentrations of MUN and PUN, and urinary excretion of $\mathrm{NH}_{3} \mathrm{~N}$ and urea $\mathrm{N}$, decreased when $\mathrm{CM}$ plus GFP replaced SBM plus GFP. Collectively, these results indicate that, compared with SBM, CM is a better companion RDP source to GFP, particularly at inclusion levels as high as $25 \%$ of the diet DM. Whereas the concentration of His in coccygeal plasma decreased with RP-Met supplementation to the diet containing SBM plus GFP, RP-Met increased circulating His in the CM plus GFP counterpart. This protein source $\times$ RP-Met interaction showed that, in comparison to SBM, CM alleviated the drop of plasma His in response to RP-Met supplementation, possibly due to improved supply of digestible His. Most variables analyzed in the present study were not affected by RP-Met, likely because any potential shortage in digestible Met was compensated by microbial protein synthesis. Further research using feed-restricted cows is needed to better understand the effects of $\mathrm{CM}$ on animal production and 
$\mathrm{N}$ metabolism without the confounding effect of DMI between SBM and CM.

\section{ACKNOWLEDGMENTS}

Partial funding was provided by the New Hampshire Agricultural Experiment Station (Durham, NH; Scientific Contribution Number 2849). This work was further supported by the USDA-National Institute of Food and Agriculture Hatch Multistate NC-2042 (Washington, DC; Project Number NH00616-R; Project Accession Number 1001855). The authors extend their gratitude to Adisseo USA Inc. (Alpharetta, GA) for donating Smartamine M and for partially funding plasma AA analytical costs. We thank the University of New Hampshire (Durham) graduate student Caren Ghedini and undergraduate students Blair Downey, Madison Prindle, Leah Caverly, Peyton Waddicor, and Paige Trusok for animal care and support during sample collection. We appreciate the scholarships from CAPES (Brasília, DF, Brazil) and CNPq (Brasília, DF, Brazil) awarded to C. Ghedini and co-author D. C. Moura, respectively. Finally, we thank the University of New Hampshire Fairchild Dairy Teaching and Research Center (Durham) manager Jon Whitehouse and his staff for excellent animal care and overall research support. The authors declare no conflicts of interest.

\section{REFERENCES}

Albrecht, J. J. 2012. Replacing corn and soybean meal in lactating dairy cow diets with field peas (Psium sativum). MS thesis. Dairy and Food Science Department, South Dakota State University, Brookings.

AOAC. 1990. Official Methods of Analysis. 15th ed. Assoc. Off. Anal. Chem., Arlington, VA.

AOAC International. 2016. Official Methods of Analysis. 20th ed. AOAC International, Gaithersburg, MD.

Baker, D. H. 2006. Comparative species utilization and toxicity of sulfur amino acids. J. Nutr. 136:1670S-1675S. https://doi.org/10 $.1093 / \mathrm{jn} / 136.6 .1670 \mathrm{~S}$.

Brito, A. F., and G. A. Broderick. 2007. Effects of different protein supplements on milk production and nutrient utilization in lactating dairy cows. J. Dairy Sci. 90:1816-1827. https://doi.org/10 $.3168 /$ jds.2006-558.

Brito, A. F., G. A. Broderick, and S. M. Reynal. 2007. Effects of different protein supplements on omasal nutrient flow and microbial protein synthesis in lactating dairy cows. J. Dairy Sci. 90:18281841. https://doi.org/10.3168/jds.2006-559.

Broderick, G. A., A. P. Faciola, and L. E. Armentano. 2015. Replacing dietary soybean meal with canola meal improves production and efficiency of lactating dairy cows. J. Dairy Sci. 98:5672-5687. https://doi.org/10.3168/jds.2015-9563.

Broderick, G. A., M. J. Stevenson, R. A. Patton, N. E. Lobos, and J. J. Olmos Colmenero. 2008. Effect of supplementing rumen-protected methionine on production and nitrogen excretion in lactating dairy cows. J. Dairy Sci. 91:1092-1102. https://doi.org/10 .3168/jds.2007-0769.

Cant, J. P., E. J. DePeters, and R. L. Baldwin. 1993. Mammary amino acid utilization in dairy cows fed fat and its relationship to milk protein depression. J. Dairy Sci. 76:762-774. https://doi.org/10 $.3168 /$ jds.S0022-0302(93)77400-7.
Chen, X. B., Y. K. Chen, M. F. Franklin, E. R. Ørskov, and W. J. Shand. 1992. The effect of feed intake and body weight on purine derivative excretion and microbial protein supply in sheep. J. Anim. Sci. 70:1534-1542. https://doi.org/10.2527/1992.7051534x.

Chirgwin, D. L., N. L. Whitehouse, A. F. Brito, C. G. Schwab, and B. K. Sloan. 2015. Evolving the plasma free AA dose-response technique to determine bioavailability of Met in RP-Met supplements. J. Dairy Sci. 98(Suppl. 2):144.

Cochran, R. C., D. C. Adams, J. D. Wallace, and M. L. Galyean. 1986. Predicting digestibility of different diets with internal markers: Evaluation of four potential markers. J. Anim. Sci. 63:1476-1483. https://doi.org/10.2527/jas1986.6351476x.

Deyl, Z., J. Hyanek, and M. Horakova. 1986. Profiling of amino acids in body fluids and tissues by means of liquid chromatography. J. Chromatogr. 379:177-250. https://doi.org/10.1016/S0378 $-4347(00) 80685-4$.

Doepel, L., and H. Lapierre. 2010. Changes in production and mammary metabolism of dairy cows in response to essential and nonessential amino acid infusions. J. Dairy Sci. 93:3264-3274. https:// doi.org/10.3168/jds.2009-3033.

Emery, R. S., L. D. Brown, and J. W. Bell. 1965. Correlation of milk fat with dietary and metabolic factors in cows fed restrictedroughage rations supplemented with magnesium oxide or sodium bicarbonate. J. Dairy Sci. 48:1647-1651. https://doi.org/10.3168/ jds.S0022-0302(65)88543-5.

Eriksson, T., and B.-O. Rustas. 2014. Effects on milk urea concentration, urine output, and drinking water intake from incremental doses of potassium bicarbonate fed to mid-lactation dairy cows. J. Dairy Sci. 97:4471-4484. https://doi.org/10.3168/jds.2013-7861.

Fekkes, D. 1996. State-of-the-art of high-performance liquid chromatographic analysis of amino acids in physiological samples. J. Chromatogr. B Biomed. Appl. 682:3-22. https://doi.org/10.1016/0378 $-4347(96) 00057-6$

Gaines, W. L., and F. A. Davidson. 1923. Relation between percentage fat content and yield of milk. Univ. Illinois Agric. Exp. Stn. Bull. 245. Univ. Illinois, Urbana.

Gidlund, H., M. Hetta, S. J. Krizsan, S. Lemosquet, and P. Huhtanen. 2015. Effects of soybean meal or canola meal on milk production and methane emissions in lactating dairy cows fed grass silagebased diets. J. Dairy Sci. 98:8093-8106. https://doi.org/10.3168/ jds.2015-9757.

Gilbery, T. C., G. P. Lardy, S. A. Soto-Navarro, M. L. Bauer, and V. L. Anderson. 2007. Effect of field peas, chickpeas, and lentils on rumen fermentation, digestion, microbial protein synthesis, and feedlot performance in receiving diets for beef cattle. J. Anim. Sci 85:3045-3053. https://doi.org/10.2527/jas.2006-651.

Huhtanen, P., M. Hetta, and C. Swensson. 2011. Evaluation of canola meal as a protein supplement for dairy cows: A review and a metaanalysis. Can. J. Anim. Sci. 91:529-543. https://doi.org/10.4141/ cjas2011-029.

Huhtanen, P., K. Kaustell, and S. Jaakkola. 1994. The use of internal markers to predict total digestibility and duodenal flow of nutrients in cattle given six different diets. Anim. Feed Sci. Technol. 48:211-227. https://doi.org/10.1016/0377-8401(94)90173-2.

Lapierre, H., G. E. Lobley, L. Doepel, G. Raggio, H. Rulquin, and S. Lemosquet. 2012. Triennial lactation symposium: Mammary metabolism of amino acids in dairy cows. J. Anim. Sci. 90:1708-1721. https://doi.org/10.2527/jas.2011-4645.

Lee, C., A. N. Hristov, K. S. Heyler, T. W. Cassidy, H. Lapierre, G. A. Varga, and C. Parys. 2012. Effects of metabolizable protein supply and amino acid supplementation on nitrogen utilization, milk production, and ammonia emissions from manure in dairy cows. J. Dairy Sci. 95:5253-5268. https://doi.org/10.3168/jds.2012-5366.

Lee, C., D. L. Morris, and P. A. Dieter. 2019. Validating and optimizing spot sampling of urine to estimate urine output with creatinine as a marker in dairy cows. J. Dairy Sci. 102:236-245. https://doi .org/10.3168/jds.2018-15121.

Leonardi, C., M. Stevenson, and L. E. Armentano. 2003. Effect of two levels of crude protein and methionine supplementation on performance of dairy cows. J. Dairy Sci. 86:4033-4042. https://doi.org/ 10.3168/jds.S0022-0302(03)74014-4. 
Martineau, R., D. R. Ouellet, and H. Lapierre. 2013. Feeding canola meal to dairy cows: A meta-analysis on lactational responses. J. Dairy Sci. 96:1701-1714. https://doi.org/10.3168/jds.2012-5740.

Martineau, R., D. R. Ouellet, and H. Lapierre. 2014. The effect of feeding canola meal on concentrations of plasma amino acids. J. Dairy Sci. 97:1603-1610. https://doi.org/10.3168/jds.2013-7125.

Martineau, R., D. R. Ouellet, and H. Lapierre. 2019. Does blending canola meal with other protein sources improve production responses in lactating dairy cows? A multilevel mixed-effects metaanalysis. J. Dairy Sci. 102:5066-5078. https://doi.org/10.3168/jds .2018-15925.

Maxin, G., D. R. Ouellet, and H. Lapierre. 2013a. Effect of substitution of soybean meal by canola meal or distillers grains in dairy rations on amino acid and glucose availability. J. Dairy Sci. 96:78067817. https://doi.org/10.3168/jds.2013-6976.

Maxin, G., D. R. Ouellet, and H. Lapierre. 2013b. Ruminal degradability of dry matter, crude protein, and amino acids in soybean meal, canola meal, corn, and wheat dried distillers grains. J. Dairy Sci. 96:5151-5160. https://doi.org/10.3168/jds.2012-6392.

Miettinen, H., and P. Huhtanen. 1997. Effects of silage fermentation and post-ruminal casein supplementation in lactating dairy cows: 2 - Energy metabolites and plasma amino acids. J. Sci. Food Agric. 74:459-468. https://doi.org/10.1002/(SICI)1097-0010(199708)74: 4<459::AID-JSFA 855>3.0.CO;2-S.

Mjoun, K., K. F. Kalscheur, A. R. Hippen, D. J. Schingoethe, and D. E. Little. 2010. Lactation performance and amino acid utilization of cows fed increasing amounts of reduced-fat dried distillers grains with solubles. J. Dairy Sci. 93:288-303. https://doi.org/10.3168/ jds.2009-2377.

Morris, D. L., L. R. Rebelo, P. A. Dieter, and C. Lee. 2018. Validating intrinsic markers and optimizing spot sampling frequency to estimate fecal outputs. J. Dairy Sci. 101:7980-7989. https://doi.org/ 10.3168/jds.2018-14717.

Morris, D. L., A. W. Tebbe, W. P. Weiss, and C. Lee. 2019. Short communication: Effects of drying and analytical methods on nitrogen concentrations of feeds, feces, milk, and urine of dairy cows. J. Dairy Sci. 102:5212-5218. https://doi.org/10.3168/jds.2019-16256.

Mulrooney, C. N., D. J. Schingoethe, K. F. Kalscheur, and A. R. Hippen. 2009. Canola meal replacing distillers grains with solubles for lactating dairy cows. J. Dairy Sci. 92:5669-5676. https://doi.org/ $10.3168 /$ jds.2009-2276.

NRC. 2001. Nutrient Requirements of Dairy Cattle. 7th rev. ed. Natl. Acad. Sci., Washington, DC.

Patton, R. A., A. N. Hristov, C. Parys, and H. Lapierre. 2015. Relationships between circulating plasma concentrations and duodenal flows of essential amino acids in lactating dairy cows. J. Dairy Sci. 98:4707-4734. https://doi.org/10.3168/jds.2014-9000.

Paula, E. M., G. A. Broderick, M. A. C. Danes, N. E. Lobos, G. I. Zanton, and A. P. Faciola. 2018. Effects of replacing soybean meal with canola meal or treated canola meal on ruminal digestion, omasal nutrient flow, and performance in lactating dairy cows. J. Dairy Sci. 101:328-339. https://doi.org/10.3168/jds.2017-13392.

Paz, H. A., and P. J. Kononoff. 2014. Lactation responses and amino acid utilization of dairy cows fed low-fat distillers dried grains with solubles with or without rumen-protected lysine supplementation. J. Dairy Sci. 97:6519-6530. https://doi.org/10.3168/jds.2014-8315.

Pereira, A. B. D., N. L. Whitehouse, K. M. Aragona, C. S. Schwab, S. F. Reis, and A. F. Brito. 2017. Production and nitrogen utilization in lactating dairy cows fed ground field peas with or without ruminally protected lysine and methionine. J. Dairy Sci. 100:62396255. https://doi.org/10.3168/jds.2016-12140.
Piepenbrink, M. S., D. J. Schingoethe, M. J. Brouk, and G. A. Stegeman. 1998. Systems to evaluate the protein quality of diets fed to lactating cows. J. Dairy Sci. 81:1046-1061. https://doi.org/10 .3168/jds.S0022-0302(98)75667-X.

Ripps, H., and W. Shen. 2012. Review: Taurine: A "very essential" amino acid. Mol. Vis. 18:2673-2686. http://www.molvis.org/ molvis/v18/a275.

Rogers, J. A., S. B. Peirce-Sandner, A. M. Papas, C. E. Polan, C. J. Sniffen, T. V. Muscato, C. R. Staples, and J. H. Clark. 1989. Production responses of dairy cows fed various amounts of rumenprotected methionine and lysine. J. Dairy Sci. 72:1800-1817. https: //doi.org/10.3168/jds.S0022-0302(89)79297-3.

Rosenthal, H. L. 1955. Determination of urea in blood and urine with diacetyl monoxime. Anal. Chem. 27:1980-1982. https://doi.org/10 .1021/ac60108a039.

Sánchez, J. M., and D. W. Claypool. 1983. Canola meal as protein supplement in dairy rations. J. Dairy Sci. 66:80-85. https://doi .org/10.3168/jds.S0022-0302(83)81756-1.

Spanghero, M., and Z. M. Kowalski. 1997. Critical analysis of N balance experiments with lactating cows. Livest. Prod. Sci. 52:113122. https://doi.org/10.1016/S0301-6226(97)00138-3.

Tomé, D., and C. Bos. 2000. Dietary protein and nitrogen utilization. J. Nutr. 130:1868S-1873S. https://doi.org/10.1093/jn/130.7 $.1868 \mathrm{~S}$.

Tyrrell, H. F., and J. T. Reid. 1965. Prediction of the energy value of cow's milk. J. Dairy Sci. 48:1215-1223. https://doi.org/10.3168/ jds.S0022-0302(65)88430-2.

Valadares, R. F. D., G. A. Broderick, S. C. V. Filho, and M. K. Clayton. 1999. Effect of replacing alfalfa silage with high moisture corn on ruminal protein synthesis estimated from excretion of total purine derivatives. J. Dairy Sci. 82:2686-2696. https://doi.org/10 .3168/jds.S0022-0302(99)75525-6.

Whitehouse, N. L., C. G. Schwab, and A. F. Brito. 2017. The plasma free amino acid dose-response technique: A proposed methodology for determining lysine relative bioavailability of rumen-protected lysine supplements. J. Dairy Sci. 100:9585-9601. https://doi.org/ 10.3168/jds.2017-12695.

Williams, E. J. 1949. Experimental designs balanced for the estimation of residual effects of treatments. Aust. J. Sci. Res., A 2:149-168. https://doi.org/10.1071/CH9490149.

Zanton, G. I., G. R. Bowman, M. Vázquez-Añón, and L. M. Rode. 2014. Meta-analysis of lactation performance in dairy cows receiving supplemental dietary methionine sources or postruminal infusion of methionine. J. Dairy Sci. 97:7085-7101. https://doi.org/10 $.3168 /$ jds.2014-8220.

Zhang, Y. D., D. P. Bu, S. C. Li, N. Zheng, X. Q. Zhou, M. Zhao, S. G. Zhao, S. L. Li, and J. Q. Wang. 2016. Technical note: Can tail arterial or tail venous blood represent external pudic arterial blood to measure amino acid uptake by mammary gland of cows? Livest. Sci. 188:9-12. https://doi.org/10.1016/j.livsci.2016.03.015.

\section{ORCIDS}

A. B. D. Pereira (ำ https://orcid.org/0000-0002-4788-0338

D. C. Moura @ https://orcid.org/0000-0002-8276-2089

N. L. Whitehouse $\odot$ https://orcid.org/0000-0003-4876-1469

A. F. Brito ๑ https://orcid.org/0000-0003-3209-5473 